\title{
Influence of rheology and morphology on foaming of PS-b-PMMA diblock copolymers and their composites with modified silica nanoparticles
}

\author{
Golda Louis Chakkalakal, ${ }^{1}$ Clarissa Abetz, ${ }^{1}$ Ulla Vainio, ${ }^{2}$ Ulrich A. Handge, ${ }^{*, 1}$ Volker Abetz ${ }^{1}$ \\ ${ }^{1}$ Institute of Polymer Research, Helmholtz-Zentrum Geesthacht, Max-Planck-Strasse 1, 21502 Geesthacht, Germany \\ ${ }^{2}$ Deutsches Elektronen-Synchrotron (DESY), Notkestrasse 85, 22607 Hamburg, Germany \\ *Corresponding author: ulrich.handge@hzg.de \\ Tel: $+49-4152-87-2446$ \\ Fax: +49-4152-87-2499
}

\begin{abstract}
In this study, the influence of rheological and morphological properties on the foaming behaviour of polystyrene-block-poly(methyl methacrylate) (PS-b-PMMA) diblock copolymers and their composites with PMMA modified silica nanoparticles is discussed. The blowing agent was carbon dioxide. Cylindrical and lamellar types of PS-b-PMMA diblock copolymers with different molecular weights were chosen in order to elucidate the influence of morphology and molecular weight on the foaming behaviour. The microphase-separated morphology of the diblock copolymers was studied by small-angle $\mathrm{x}$-ray scattering and microscopic investigations. The rheological behaviour of the materials under shear was analyzed using linear viscoelastic shear oscillations and creep experiments in order to probe the microstructure at different time scales. High pressure differential scanning calorimetry measurements indicate that the blowing agent carbon dioxide was dissolved in the PS and in the PMMA domains. Generally, the diblock copolymers of our study with a cylindrical morphology led to foams with a lower density than the ones with a lamellar morphology. This effect indicates that large stresses are necessary to deform lamellar structures during nucleation and expansion of foam cells. The diblock copolymer with a cylindrical morphology and polystyrene as the matrix was associated with an $\omega$-independent plateau at low frequencies of the shear oscillations. After foaming, the cell walls and the surface of the foamed PS- $b$-PMMA diblock copolymer with the polystyrene matrix depicted the cylindrical morphology of the microphase-separated structure.
\end{abstract}

Keywords: Block copolymers, polymer foams, morphology 


\section{Introduction}

The ability of block copolymers to combine the dissimilar properties of homopolymer segments in a single material through their ability of forming self-assembled structures at the molecular level is an area of intensive research interest [1-3]. By controlling the degree of polymerization and the volume fraction of the blocks, one can fine-tune the microstructure of block copolymers for applications in a variety of industrial fields: toughness modifiers, membranes, surface modifiers, compatibilizers, biocompatible materials, electric and optical applications [4-6]. On the other hand, thermoplastic polymer foams have been widely used in a variety of applications, e.g., membranes, insulation, absorbents, cushion and weight-bearing structures [7-11]. Environmentally benign, non-flammable and inexpensive gas like carbon dioxide $\left(\mathrm{CO}_{2}\right)$ has been widely used in polymer processing and hence as a porogenic agent [12-14]. The combination of block copolymers with foam processing opens a new route for preparation of multiscale structured materials. By controlling the temperature and pressure, one can optimize the expansion ratio of the foam during processing. Depending on the application, the objective of foaming is to achieve a tailor-made morphology, i.e. an open or a closed cell structure. For example, the molecular architecture of polyolefins influence strainhardening in melt elongation and hence the properties in foam processing [15]. In conclusion, a strong need exists in order to understand the influence of material and processing parameters on the preparation of polymer foams.

Processing of polymers is strongly associated with their rheological properties. During foaming, a polymeric melt is exposed to shear and elongational stresses. Hence the rheological properties and the flow induced deformations in polymer systems are of high relevance in foaming, e.g., the correlation between composition and viscosity [16] and the influence of carbon dioxide on rheological properties of multiphase polymer blends [17]. Generally, the blowing agent influences the thermal and viscoelastic properties of the polymer [18-20]. The effect of addition of micron-sized particles on the cell nucleation has been 
elucidated by Park et al. [21]. Several studies were devoted to the foaming of polymer blends using carbon dioxide [17] or organic liquids [22]. In contrast to homopolymer and polymer blends, a much smaller number of publications is devoted to foaming of block copolymers. The work of Spitael et al. revealed that block copolymer micelles did not lower the work for nucleation of foam cells [23]. A special feature of block copolymers is the aspect that viscoelastic properties are influenced by the microphase separation of block copolymers and thus by the order-disorder temperature [24].

Theories predicting phase transition temperatures of AB-type diblock copolymers are well documented [25-28]. Siripurapu et al. [14] noticed the variation of the order-disorder transition temperature of PS- $b$-PMMA diblock copolymers of a given molecular weight with silica which were functionalized with hydroxyl, methacrylate and octyl groups. The sorption of carbon dioxide in diblock copolymers can lead to a depression of the order-disorder transition (ODT) [29, 30]. Studies on ODT of pristine PS- $b$-PMMA block copolymers were carried out by several research groups using small-angle neutron and x-ray scattering methods. These measurements were based on spectra of low molecular weight block copolymers. In most studies, systems with nearly equal compositions of both blocks (leading to a lamellar structure) and with a low degree of polymerization were considered [31-40].

Initial studies on foaming of block copolymers reported the formation of ordered pore structures in the nanoscale range from thin films of PS-b-PMMA/PMMA blends through selective solvent swelling and subsequent reannealing [41]. Yokoyama et al. [42-44] developed nanocellular structures from thin films of block copolymers with a polystyrene matrix and a fluorine containing block (spherical morphology) by $\mathrm{CO}_{2}$ foaming. Later, Taki et al. [45] created nanowells up to a depth of approximately $2 \mathrm{~nm}$ from thin films of PS- $b$ PMMA block copolymers with polystyrene as a matrix and a spherical morphology. The relation between processing parameters and the microstructure of foams for films of a fluorinated ethylene propylene copolymer was studied by Zirkel et al. [46]. The size of the 
cells mainly depended on the foaming temperature. The nucleation rate decreased with lower depressurization rate [46].

The present study focuses on the influence of molecular weight and the degree of polymerization on the formation of foams of amorphous PS- $b$-PMMA diblock copolymers in the bulk state. PS-b-PMMA diblock copolymers were chosen as model systems. The blowing agent was carbon dioxide. The studies discussed above on creating pore structures were carried out using thin films of low molecular weight block copolymers with a film thickness below $1 \mu \mathrm{m}$. The motivation behind choosing high molecular weight diblock copolymers in this work is due to the advantage of achieving better mechanical properties. In contrast to previous studies, the present study is devoted to the influence of cylindrical and lamellar morphology for a range of diblock copolymers of high molecular weights with a high degree $N$ of polymerization ( $N$ larger than 1000) on rheological properties and foam processing. In this work results of rheological measurements are combined with SAXS profiles in order to interpret the morphological ordering in different diblock copolymer systems. The variation in density and morphology of foam structures prepared from diblock copolymers and their composites with PMMA grafted silica with temperature is investigated. This work presents a first attempt to prepare multiscale structured bulk foams by combining the cell structure in the micrometre range with the microphase separated structure in the range of 30 nanometres.

\section{Experimental}

\subsection{Materials}

PS-b-PMMA diblock copolymers with a lamellar and a cylindrical morphology, respectively, were synthesized via sequential anionic block copolymerization of styrene and methyl methacrylate (MMA). The anionic copolymerization of styrene and MMA was carried out in tetrahydrofuran (THF) at $-78^{\circ} \mathrm{C}$ in the presence of $\mathrm{LiCl}$ (high purity, Sigma-Aldrich $\mathrm{GmbH}$, 
Schnelldorf) under purified argon using sec-butyl lithium as an initiator. The results of molecular characterization data for these diblock copolymers are summarized in Table 1.

MMA for surface initiated atom transfer (SI-ATR) polymerization was purified by first passing through an alumina column followed by distillation from calcium hydride. (3glycidoxypropyl) trimethoxysilane (GPS) (>98\%) was purchased from Sigma-Aldrich GmbH (Schnelldorf) and used as received. Triethylamine ( $\left.\mathrm{Et}_{3} \mathrm{~N}, \geq 99 \%\right)$, 2-bromoisobutyryl bromide (2-BriB, 98\%), $N, N, N^{\prime}, N^{\prime}, N^{\prime \prime}$-pentamethyldiethylenetriamine (PMDETA), hydrofluoric acid (HF, 48 wt\%), Aliquot 336 ( $N$-methyl- $N, N$-dioctyloctan-1-ammonium chloride), ethyl-2bromoisobutyrate (2-EBriB, 98\%) and copper(I) bromide (CuBr, 99.99\%) stored under vacuum, were used as received from Sigma-Aldrich GmbH. Silica suspension (Ludox-HS) was provided by Aldrich chemicals and also used as received. These suspensions consisted of $40 \mathrm{wt} \%$ of colloidal silica particles in water (specific area $=220 \mathrm{~m}^{2} / \mathrm{g}, 4.7 \mathrm{OH}$ groups $/ \mathrm{nm}^{2}$ ). Dynamic light scattering measurement results obtained from dilute dispersions indicated that the distribution had an effective mean diameter of $14 \pm 3 \mathrm{~nm}$.

Table 1. Physical properties of the PS-b-PMMA diblock copolymers at ambient conditions

a)

\begin{tabular}{cccccc}
\hline Material & Abbreviation & $\boldsymbol{M}_{\mathbf{n}}(\mathbf{k g} / \mathbf{m o l})^{\boldsymbol{a}}$ & $\boldsymbol{M}_{\mathbf{w} / \boldsymbol{M}_{\mathbf{n}}{ }^{\boldsymbol{b}}}$ & $\boldsymbol{\Phi}_{\text {PMMA }^{\boldsymbol{c}}}$ & $\boldsymbol{N}^{\boldsymbol{d}}$ \\
\hline $\mathrm{S}_{110} \mathrm{M}_{125}(\mathrm{~L} 1)$ & $\mathrm{SM}(\mathrm{L} 1)$ & 235 & 1.02 & 0.49 & 2317 \\
$\mathrm{~S}_{66} \mathrm{M}_{68}(\mathrm{~L} 2)$ & $\mathrm{SM}(\mathrm{L} 2)$ & 134 & 1.01 & 0.47 & 1322 \\
$\mathrm{~S}_{46} \mathrm{M}_{51}(\mathrm{~L} 3)$ & $\mathrm{SM}(\mathrm{L} 3)$ & 97 & 1.01 & 0.51 & 953 \\
$\mathrm{~S}_{56} \mathrm{M}_{52}(\mathrm{~L} 4)$ & $\mathrm{SM}(\mathrm{L} 4)$ & 108 & 1.02 & 0.42 & 1005 \\
$\mathrm{~S}_{42} \mathrm{M}_{121}(\mathrm{C} 1)$ & $\mathrm{SM}(\mathrm{C} 1)$ & 163 & 1.01 & 0.72 & 1611 \\
$\mathrm{~S}_{60} \mathrm{M}_{165}(\mathrm{C} 2)$ & $\mathrm{SM}(\mathrm{C} 2)$ & 225 & 1.02 & 0.70 & 2237 \\
$\mathrm{~S}_{38} \mathrm{M}_{100}(\mathrm{C} 3)$ & $\mathrm{SM}(\mathrm{C} 3)$ & 138 & 1.02 & 0.71 & 1378 \\
\hline
\end{tabular}

b)

\begin{tabular}{cccccc}
\hline Material & Abbreviation & $\boldsymbol{M}_{\mathbf{n}}(\mathbf{k g} / \mathbf{m o l})^{a}$ & $\boldsymbol{M}_{\mathbf{w} / \boldsymbol{M}_{\mathbf{n}}{ }^{b}}$ & $\boldsymbol{\Phi}_{\mathbf{P S}}{ }^{c}$ & $\boldsymbol{N}^{d}$ \\
\hline $\mathrm{S}_{100} \mathrm{M}_{39}(\mathrm{C} 4)$ & $\mathrm{SM}(\mathrm{C} 4)$ & 139 & 1.02 & 0.72 & 1376 \\
\hline
\end{tabular}

$\mathrm{S}_{\mathrm{x}} \mathrm{M}_{\mathrm{y}}$ : The subscripts $\mathrm{x}$ and $\mathrm{y}$ denotes the molecular weight $(\mathrm{kg} / \mathrm{mol})$ of respective blocks calculated from NMR. L1, L2, L3, L4 and C1, C2, C3, C4 in the parentheses denote the block copolymers with lamellar (L) and cylindrical (C) morphology, respectively. C4 in the parenthesis denotes the block copolymer with polystyrene as the major component. ${ }^{a}$ Determined by size exclusion chromatography (SEC) which was calibrated by PS standards. ${ }^{b}$ Determined by SEC using universal calibration. ${ }^{c}$ Volume fractions are determined by ${ }^{1} \mathrm{H}$ nuclear magnetic resonance. The density of polystyrene and poly(methyl methacrylate) was taken as $1.09 \mathrm{~g} / \mathrm{cm}^{3}$ and $1.18 \mathrm{~g} / \mathrm{cm}^{3}$ respectively for calculation [47]. ${ }^{d}$ Degree of polymerization. 


\subsection{Molecular characterization}

The number average $\left(M_{\mathrm{n}}\right)$ and weight average $\left(M_{\mathrm{w}}\right)$ of the molar masses were determined using size exclusion chromatography (SEC) in THF at $30{ }^{\circ} \mathrm{C}$ with a flow rate of $1 \mathrm{~mL} \mathrm{~min}{ }^{-1}$. Experiments were performed on a Waters instrument with 4 PSS SDV gel columns $\left(10,10^{2}\right.$, $10^{3}, 10^{4} \mathrm{~nm}, 8 \mathrm{~mm}$ (internal diameter) x $300 \mathrm{~mm}$ (length), PSS Polymer Standards Service GmbH, Mainz, Germany). Polystyrene standards were used for calibration.

The particle size distribution in solution was determined by dynamic light scattering (DLS). An ALV CGS-3 goniometer (ALV-Laser Vertriebsgesellschaft GmbH, Langen, Germany) equipped with a $22 \mathrm{~mW}$ He-Ne Laser $\left(\lambda_{0}=632.8 \mathrm{~nm}\right.$, vertically polarized; model $1145 \mathrm{P}$, JDS Uniphase Corporation Santa Rosa (CA) USA) was employed. The apparent hydrodynamic radius $\left(R_{\mathrm{h}}{ }^{a p p}(q)\right)$ was calculated from the correlation function employing either a second order cumulant fit or the so-called ALV-regularized fit of $g^{2}(t)$-type (based on the CONTIN algorithm) covering a time interval ranging typically from 375 ns to $1 \mathrm{~ms}$.

${ }^{1} \mathrm{H}$ nuclear magnetic resonance spectroscopy $\left({ }^{1} \mathrm{H}-\mathrm{NMR}\right)$ using the solvent peak as a reference was carried out on a Bruker AV-300 FT-NMR spectrometer at $300 \mathrm{MHz}$.

\subsection{Morphological characterization}

The morphology of diblock copolymers was investigated by transmission electron microscopy (TEM) using FEI Tecnai G2 F20 operated at $200 \mathrm{kV}$. The morphology was analysed using ultra-thin sections of compression moulded samples prepared by an ultramicrotome (Leica EM FCS) equipped with a diamond knife. The contrast between the microphases of the diblock copolymer was achieved by exposing the sample to $\mathrm{RuO}_{4}$ vapour.

Scanning electron microscopy (SEM) investigations were carried out using a LEO Gemini $1550 \mathrm{VP}$ operated at a voltage of 3 or $5 \mathrm{kV}$, respectively, under high vacuum with a $15 \mu \mathrm{m}$ aperture. The specimens were fractured under liquid nitrogen with 2-propanol and fitted with conductive-carbon paste in order to expose internal cellular structures. Selected micrographs 
without the use of the carbon paste were prepared in order to detect the cylindrical morphology of the diblock copolymer with a polystyrene matrix.

The bulk morphology of diblock copolymers was studied by means of small-angle x-ray scattering (SAXS). The diblock copolymer films used for the analysis were cast from the nonselective solvent tetrahydrofuran and dried in a Teflon ${ }^{\circledR}$ dish at a temperature of $140{ }^{\circ} \mathrm{C}$ under vacuum leading to a slow evaporation of the solvent. The SAXS measurements were carried out at B1 beamline of DORIS III synchrotron storage ring at DESY (Hamburg, Germany). For SAXS, a 2D detector (Pilatus 1M and 300k, Dectris) was placed at a sample-to-detector distance of 3580 mm while simultaneously wide-angle x-ray scattering (WAXS) was measured using a 1D detector (Mythen, Dectris) placed at a sample-to-detector distance of $135 \mathrm{~mm}$. The x-ray wavelength $\lambda$ was set to $0.103 \mathrm{~nm}$, and beam size on the sample was $1 \mathrm{~mm} \times 0.6 \mathrm{~mm}$. The SAXS measurements were carried out under vacuum conditions and heating was established using a ceramic heating block. During heating, the samples were wrapped up in aluminum foil to assure good heat conductance and heated step-wise up to $300{ }^{\circ} \mathrm{C}$ with 1 min stabilization time before each SAXS measurement of $1 \mathrm{~min}$, and finally cooled down to $25^{\circ} \mathrm{C}$. The heating rate between the steps was $5{ }^{\circ} \mathrm{C} / \mathrm{min}$ while cooling back to room temperature was uncontrolled. The measurements were normalized by x-ray transmission of the sample at each temperature and the background signal was subtracted before the analysis of the SAXS data. In this article, the magnitude of the scattering vector $q$ is defined by $q=4 \pi \sin (\theta) / \lambda$, where $\theta$ is half of the scattering angle.

\subsection{Preparation and characterization of batch foams}

Polymer foams were prepared using the technique of batch foaming. A stainless steel highpressure vessel equipped with a three way valve was connected to the high-pressure carbon dioxide source. The carbon dioxide was provided by Linde Gas (Pullach, Germany) and has a purity of $99.995 \%$. Previously annealed films (at $140{ }^{\circ} \mathrm{C}$ ) of PS- $b$-PMMA diblock copolymers were compression moulded at $200{ }^{\circ} \mathrm{C}$. The specimens had dimensions of $20 \mathrm{~mm}$ length, 10 
mm width and $0.36 \mathrm{~mm}$ thickness and were placed in the high-pressure vessel and loaded with carbon dioxide at $40{ }^{\circ} \mathrm{C}$ for 1 week under a pressure of 40 bar using a pressure regulator. The time of saturation strongly depends on the geometrical dimensions of the sample. A simple estimation for the time $t_{\mathrm{sat}}$ of saturation is given by $t_{\mathrm{sat}}=0.202 L^{2} / D$ [48], where $L$ is the thickness of the film and $D$ the coefficient of diffusion. Insertion of $L=0.36 \mathrm{~mm}$ and $D \approx$ $1 \times 10^{-12} \mathrm{~m}^{2} / \mathrm{s}$ yields $t_{\mathrm{sat}}=26180 \mathrm{~s}=7.3 \mathrm{~h}$ which shows that the loading time of 1 week is large enough in order to guarantee complete saturation of the sample. The vessel was kept in a thermostat while maintaining the pressure. The depressurization was carried out at a rate of approximately $0.5 \mathrm{bar} / \mathrm{s}$. The sample was foamed at temperatures of $220{ }^{\circ} \mathrm{C}, 260{ }^{\circ} \mathrm{C}$ and 300 ${ }^{\circ} \mathrm{C}$ for a period of $45 \mathrm{~s}$ in hot air. After $45 \mathrm{~s}$ the expansion of the sample was finished. Then we quenched the resultant foam structure by placing the sample in a cold water bath.

Density measurements were carried out with a Mettler-Toledo balance using perfluorocompound, FC-770 Fluorinert ${ }^{\mathrm{TM}}$ as the auxiliary liquid. Densities of the auxiliary liquid and air were chosen as $1.7799 \mathrm{~g} / \mathrm{cm}^{3}$ [49] and $0.0012 \mathrm{~g} / \mathrm{cm}^{3}$ [50], respectively, for the calculation of density.

\subsection{Rheological characterization}

\subsubsection{Sample preparation}

Solution cast films of the PS-b-PMMA diblock copolymers were prepared from the solvent tetrahydrofuran. The solvent was allowed to evaporate slowly over more than one week at room temperature. Then the films were dried under vacuum for 2 days followed by drying at $140{ }^{\circ} \mathrm{C}$ (by step wise heating) for 3-4 days in order to obtain a constant weight sample. ${ }^{1} \mathrm{H}$ NMR was used to confirm that the films were free of solvent. These cast films were used for preparing specimens by compression moulding. For the composite preparation, the powder of the diblock copolymers and the modified nanoparticles with 1 wt\% silica were separately weighted and then mixed together by means of solvent. Then the solution was stirred for one 
day. After stirring, the bubble free solution was cast slowly and evenly on a Bytac ${ }^{\circledR}$ coated glass plate. Finally, these cast films were dried in vacuum oven.

The specimens for shear rheology had a diameter of $8 \mathrm{~mm}$. The solvent cast films prepared above were used for compression moulding at $200{ }^{\circ} \mathrm{C}$. Initially the sample was allowed to melt for $90 \mathrm{~s}$ under slight pressure followed by applying vacuum for $70 \mathrm{~s}$ in order to remove air trapped between stacked films and then applied a force of $50 \mathrm{kN}$ for $200 \mathrm{~s}$. The samples were cooled for $10 \mathrm{~min}$.

\subsubsection{Shear rheology}

The rotational rheometer MCR502 (Anton Paar GmbH, Austria) was used for measurements in the oscillatory mode. A parallel plates geometry was used with a plate diameter of $8 \mathrm{~mm}$. The measurements were performed at constant temperature ranging from $150{ }^{\circ} \mathrm{C}$ to $220^{\circ} \mathrm{C}$ as a function of angular frequency $\omega$ in the dynamic mode with a gap of $1 \mathrm{~mm}$ under nitrogen purge. The angular frequency was varied between $10^{-2}$ and $10^{2} \mathrm{rad} / \mathrm{s}$, starting at the highest frequency. The strain amplitude $\gamma_{0}$ was $5 \%$ in the whole frequency range to ensure linearity. The data measured at different temperatures were shifted using the software LSSHIFT (Freiburg Materials Research Center, Freiburg) in order to construct master curves following the time-temperature superposition principle [51, 52].

\subsubsection{Creep experiments}

In order to determine the viscoelastic properties at large times, creep experiments were carried out with the rotational rheometer MCR502 (Anton Paar GmbH, Austria) using a parallel plates geometry under nitrogen purge. The diameter of the plates was $8 \mathrm{~mm}$ and the gap was set to $1 \mathrm{~mm}$. The measurements were performed at $220^{\circ} \mathrm{C}$. Before each creep experiment, the linear viscoelastic range for each sample was checked by amplitude sweeps as a function of shear stress. The shear stress in the creep interval was $500 \mathrm{~Pa}$. The creep time was $10000 \mathrm{~s}$. 
The thermal stability of the block copolymer $\mathrm{S}_{42} \mathrm{M}_{121}(\mathrm{C} 1)$ was checked at $220{ }^{\circ} \mathrm{C}$ as a function of time $t$ in the dynamic mode with a gap of $1 \mathrm{~mm}$ under nitrogen purge. The angular frequency $(\omega)$ and strain amplitude $\left(\gamma_{0}\right)$ were kept at $0.1 \mathrm{rad} / \mathrm{s}$ and $5 \%$, respectively, throughout the measurement. The data did not indicate any significant degradation.

\subsection{Sorption and thermal properties}

The amount of carbon dioxide that was dissolved during the batch foaming process at $40^{\circ} \mathrm{C}$ and a pressure of 40 bar was determined by sorption measurements. A magnetic balance (Rubotherm GmbH, Bochum, Germany) that was connected to a carbon dioxide cylinder was used. The sorption experiments were carried out using powder of two selected block copolymers $(\mathrm{SM}(\mathrm{C} 1)$ and $\mathrm{SM}(\mathrm{L} 2))$ at $40^{\circ} \mathrm{C}$. The pressure was varied from 0 to 40 bar in increments of 10 bar. At each pressure level, the mass increase caused by sorption of $\mathrm{CO}_{2}$ was determined by measuring the buoyancy force. The weight concentration of $\mathrm{CO}_{2}$ at saturation corresponded to the equilibrium value of specific uptake (ratio of absorbed mass and mass of sample powder).

The variation of the glass transition of polystyrene and poly(methyl methacrylate) blocks of the PS- $b$-PMMA diblock copolymers at a pressure of 1 bar, 10 bar and 20 bar in a carbon dioxide $\left(\mathrm{CO}_{2}\right)$ atmosphere was measured using a DSC device HP DSC1 (Mettler-Toledo AG, Greifensee, Switzerland). Standard aluminum pans of $50 \mu \mathrm{L}$ were used to encapsulate the samples with a mass of approximately $10 \mathrm{mg}$. Dynamic heating and cooling scans were performed. The DSC measurements at ambient conditions (1 bar) were carried out under nitrogen atmosphere at a constant rate of $10^{\circ} \mathrm{C} / \mathrm{min}$. The second heating cycle was analyzed. The high pressure DSC measurements were carried out in several intervals and performed in a $\mathrm{CO}_{2}$ atmosphere. Initially, the sample was preheated from $25^{\circ} \mathrm{C}$ to $200{ }^{\circ} \mathrm{C}$ and then cooled to room temperature under 1 bar atmosphere for a constant rate of $10{ }^{\circ} \mathrm{C} / \mathrm{min}$ in order to erase the thermal history. Then the pressure was increased up to 10 bar and 20 bar, respectively. 
Since the diameter of a powder particle is in the order of $50 \mu \mathrm{m}$, the estimated time of saturation with carbon dioxide $\left(D \approx 10^{-12} \mathrm{~m}^{2} / \mathrm{s}\right)$ is in the order of $t_{\mathrm{sat}}=2500 \mathrm{~s}$. Indeed, our sorption experiments revealed that the powder sample was completely loaded with $\mathrm{CO}_{2}$ within 2 h. Therefore the required pressure (10 bar or 20 bar) was applied for $2 \mathrm{~h}$ at a temperature of $40{ }^{\circ} \mathrm{C}$ in order to achieve a complete saturation of the sample with $\mathrm{CO}_{2}$. The final cycle involved heating of the sample to $200{ }^{\circ} \mathrm{C}$ and further cooling to room temperature under $\mathrm{CO}_{2}$ atmosphere in order to measure the decrease of the glass transition temperature.

\subsection{ATRP of MMA from 2-bromoisobutyrate functional colloids}

Silica nanoparticle functionalization by epoxy silane for anchoring ATRP initiator followed by grafting PMMA chains were synthesized according to the procedure reported before [53]. The degrafted (by treating with HF and Aliquot 336) PMMA chains have $M_{\mathrm{n}}$ and $M_{\mathrm{w}} / M_{\mathrm{n}}$ of $21000 \mathrm{~g} / \mathrm{mol}$ and 1.1 respectively. In this paper, the modified silica nanoparticles are thus abbreviated by $\mathrm{M}_{21} \mathrm{Si}$. The dynamic light scattering measurements showed that the PMMA modified particles had an approximate hydrodynamic diameter of $26 \mathrm{~nm}$.

\section{Results and discussion}

\subsection{Characterization of the morphological properties of PS-b-PMMA diblock copolymers by TEM and SAXS}

First, the morphology of the diblock copolymers as a function of temperature is discussed. We analyzed the combined information from small-angle x-ray scattering and microscopic measurements to investigate the influence of molecular weight and morphology on the rheological properties and the foaming behaviour of the block copolymers and their composites.

The morphology of compression moulded specimens of the block copolymer with a lamellar and a cylindrical morphology before the foaming experiments is shown in Fig. 1. The 
microphase separated structure in Fig. 1(a) shows lamellae of PS and PMMA domains. The micrograph reveals that the lamellar morphology is not characterized by a perfectly ordered structure. This irregular morphology arises from the large molecular weight of the block copolymer chains. Because of the large molecular weight, the relaxation processes in the molten state are very slow such that no equilibrium structure was achieved during compression moulding. Figure 1(b) presents the morphology of the composite SM(L2) with 1 wt\% silica nanoparticles. The composite was also stretched in the melt. The micrograph indicates that agglomerates are still present in the composite. Hence the distribution of nanoparticles is not completely uniform. Figure 1(c) depicts the microstructure of the sample with a cylindrical morphology (SM(C1)). Similar to the block copolymer with a lamellar morphology, the microstructure was not completely equilibrated.

(a)
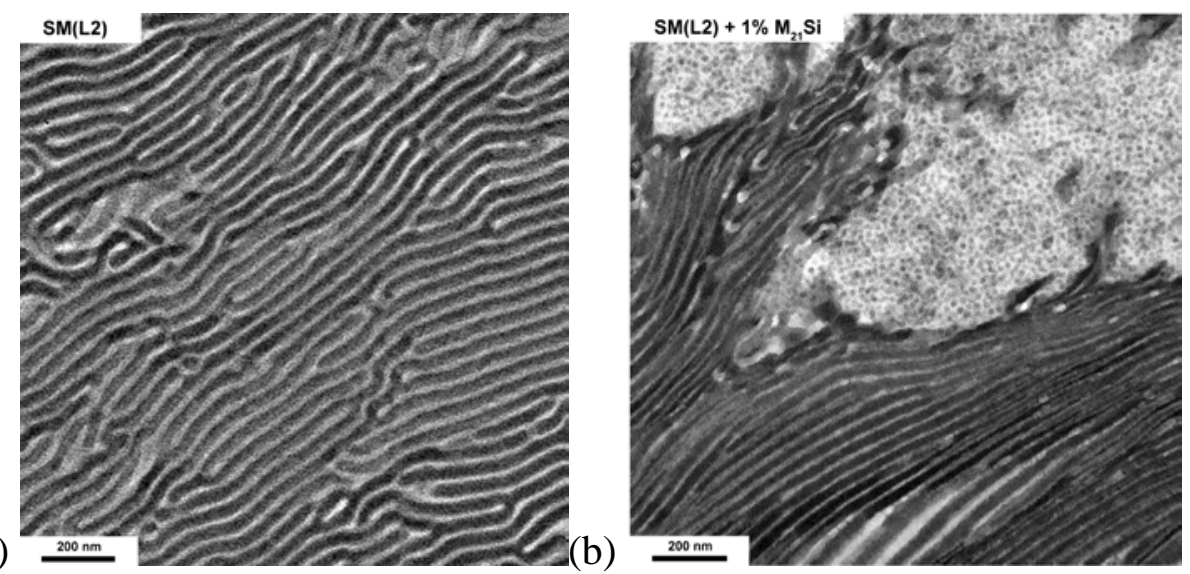

(c)

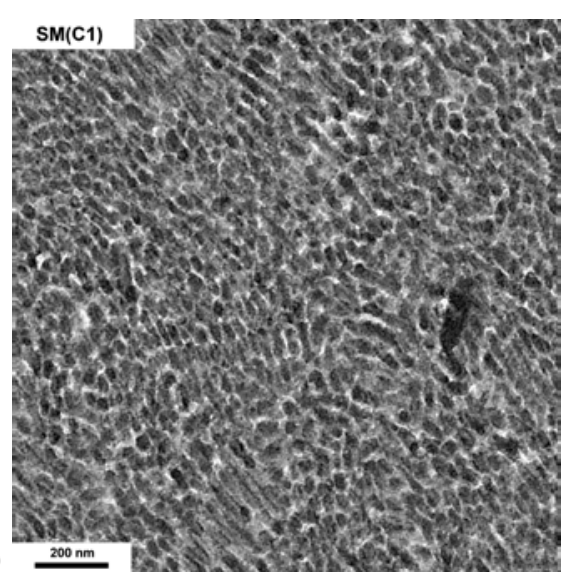

Figure 1. Transmission electron micrographs of ultra-thin cross sections of compression moulded diblock copolymer specimens from (a) lamellar $\mathrm{S}_{66} \mathrm{M}_{68}(\mathrm{~L} 2)$, (b) lamellar $\mathrm{S}_{66} \mathrm{M}_{68}(\mathrm{~L} 2)$ with 1 wt\% silica nanoparticles and (c) cylindrical $\mathrm{S}_{42} \mathrm{M}_{121}(\mathrm{C} 1)$ diblock copolymers. The samples were stained with $\mathrm{RuO}_{4}$. The white phase corresponds to PMMA and the dark phase to PS domains. 
The scattering curves of the compression-moulded films of the diblock copolymers with a lamellar $(\mathrm{SM}(\mathrm{L}))$ and a cylindrical morphology $(\mathrm{SM}(\mathrm{C}))$ at room temperature are shown in Fig. 2. The block copolymers of the $\mathrm{SM}(\mathrm{L})$ series depict scattering peaks which are in accordance with a lamellar structure, i.e. an equidistant distribution of the peaks. The peaks at $q^{*}$ and $3 q^{*}$ are generally more clearly visible than the other peaks, which is due to the rather similar volume fractions of the two blocks (for the volume fraction of 0.5 the even high order peaks would disappear). A decreasing molecular weight yields an increase of $q^{*}$ which corresponds to a smaller long period. The scattering peaks of the block copolymers of the SM(C) series can be interpreted by a poorly-ordered 2D-hexagonal arrangement of cylindrical domains with peaks at $q^{*}, \sqrt{3} q^{*}, 2 q^{*}, \sqrt{7} q^{*}$. Similar to the specimens of the $\operatorname{SM}(\mathrm{L})$ series, a decreasing molecular weight yields a decrease of the long period.
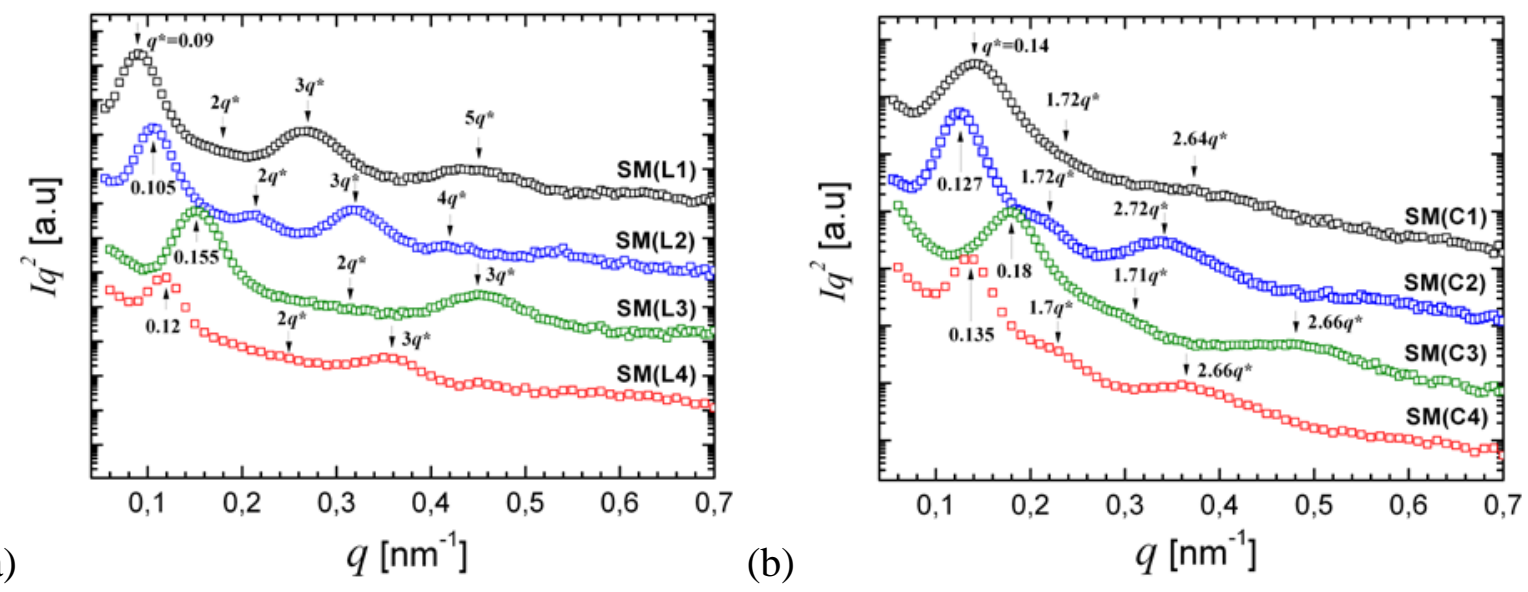

Figure 2. Intensity $\left(I q^{2}\right)$ as a function of scattering vector $(q)$ for films of pristine block copolymers with (a) a lamellar and (b) a cylindrical morphology. The curves were shifted for clarity.

The evolution of the morphology with temperature was investigated by analyzing the azimuthally averaged SAXS patterns recorded for a heating cycle starting from room temperature up to $300{ }^{\circ} \mathrm{C}$ which was followed by a rapid quench to room temperature (see Fig. 3). The sample preparation process did not lead to a perfectly equilibrated microphaseseparated structure. During the heating interval at temperatures above the glass transition 
temperatures of both blocks, the mobility of the polymer chains was sufficiently high such that a more equilibrated morphology was achieved. Therefore, the SAXS profiles before and after heating up to $300{ }^{\circ} \mathrm{C}$ differed, see Fig. 3. After cooling to room temperature the width of the peaks was smaller because of the more equilibrated morphology. Furthermore, the position of some peaks also shifted during heating. An ordered lamellar arrangement was observed for $\mathrm{S}_{110} \mathrm{M}_{125}(\mathrm{~L} 1)$ before heating up to $300{ }^{\circ} \mathrm{C}$ with a long period of $L=2 \pi / q^{*}=70$ $\mathrm{nm}\left(q^{*}=0.09 \mathrm{~nm}^{-1}\right.$, see Fig. 2(a)). After cooling to room temperature, the scattering peaks were sharper. The initial long period of the two block copolymers $\mathrm{S}_{66} \mathrm{M}_{68}(\mathrm{~L} 2)$ and $\mathrm{S}_{46} \mathrm{M}_{51}(\mathrm{~L} 3)$ was $60 \mathrm{~nm}\left(q^{*}=0.105 \mathrm{~nm}^{-1}\right.$, see Fig. 2(a)) and $41 \mathrm{~nm}\left(q^{*}=0.155 \mathrm{~nm}^{-1}\right.$, see Fig. 2(a)), respectively. Increasing the molecular weight of polystyrene, cf. the data for $\mathrm{S}_{56} \mathrm{M}_{52}(\mathrm{~L} 4)$, an ordered lamellar system was observed before heating up to $300{ }^{\circ} \mathrm{C}$ (with $L=52 \mathrm{~nm}$, see Fig. 3(d)). After heating to a temperature of $300^{\circ} \mathrm{C}$, an increase of the long period to $L=63 \mathrm{~nm}$ was observed.

A much stronger temperature dependence was observed for the block copolymers with a cylindrical morphology (see Fig. 3). Before heating, the position of the main scattering peak in $\mathrm{S}_{42} \mathrm{M}_{121}(\mathrm{C} 1)$ is $q^{*}=0.14 \mathrm{~nm}^{-1}$ (lattice plane spacing $d_{10}=2 \pi / q^{*}=45 \mathrm{~nm}$, see Fig. 2(b)). Because of the not equilibrated morphology, the higher order peaks are not visible. After heating and quenching the system to $24{ }^{\circ} \mathrm{C}$, the lattice plane spacing was $58 \mathrm{~nm}$ and the scattering curve depicts a hexagonal morphology (see Fig. 3(e)). The block copolymer with the highest molecular weight, $\mathrm{S}_{60} \mathrm{M}_{165}(\mathrm{C} 2)$, also was hexagonally ordered $\left(q^{*}=0.127 \mathrm{~nm}^{-1}\right.$; $q^{*}, \sqrt{3} q^{*}, \sqrt{ } 7 q^{*}, d_{10}=50 \mathrm{~nm}$, see Fig. 2(b)). After cooling to room temperature, the lattice plane spacing was $d_{10}=74 \mathrm{~nm}$. The system $\mathrm{S}_{38} \mathrm{M}_{100}(\mathrm{C} 3)$ depicts weakly pronounced scattering peaks at $q^{*}, \sqrt{ } 3 q^{*}, \sqrt{ } 7 q^{*}$ before heating up to $300^{\circ} \mathrm{C}\left(q^{*}=0.18 \mathrm{~nm}^{-1}\right.$ with $d_{10}=35$ nm, see Fig. 2(b)). The diblock copolymer $\mathrm{S}_{100} \mathrm{M}_{39}(\mathrm{C} 4)$ has a polystyrene matrix and an initial morphological order, $q^{*}=0.135 \mathrm{~nm}^{-1} ; q^{*}, \sqrt{ } 3 q^{*}, \sqrt{ } 7 q^{*}$ and a lattice plane spacing of $d_{10}=45$ 
nm (see Fig. 2(b)). The lattice plane spacing of the cylindrical morphology after heating was $d_{10}=60 \mathrm{~nm}$.
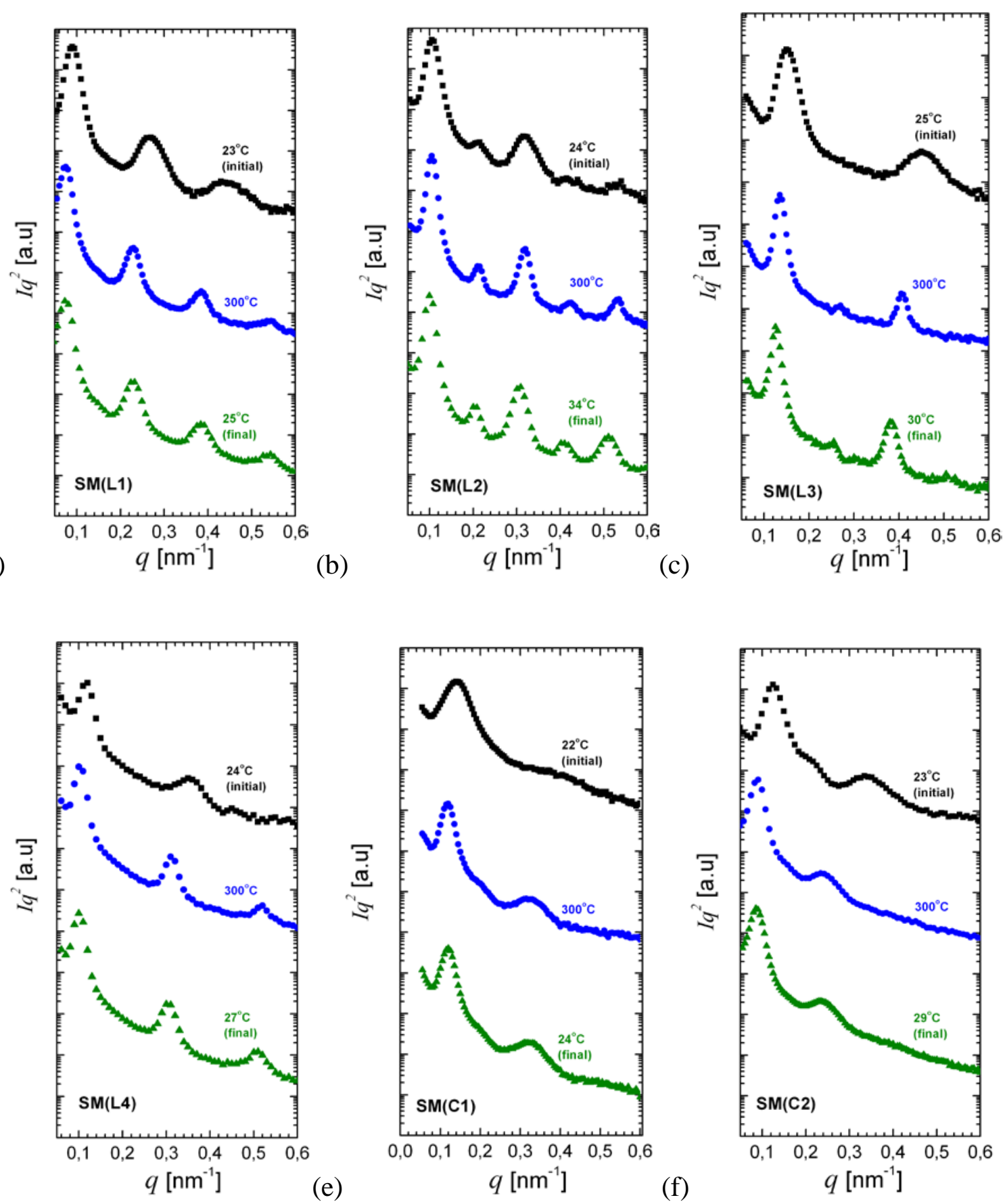

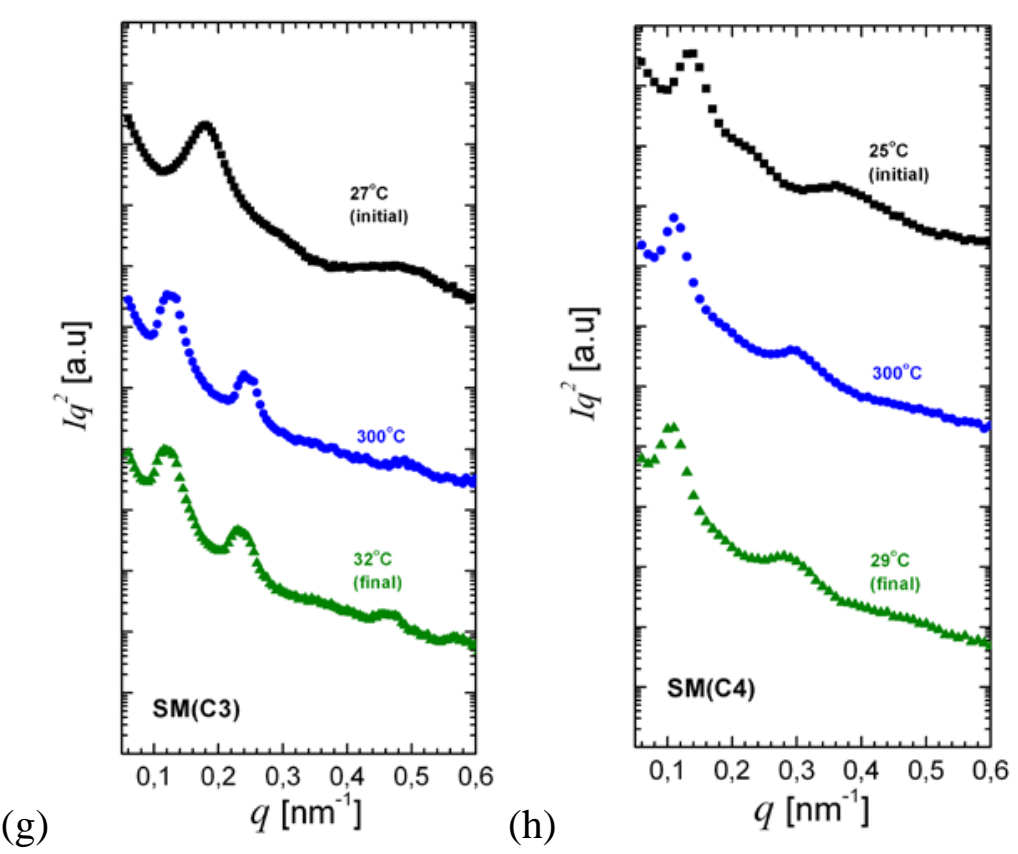

Figure 3. Intensity $\left(I q^{2}\right)$ as a function of scattering vector $(q)$ as determined by temperature dependent scattering experiments with (a) $\mathrm{S}_{110} \mathrm{M}_{125}(\mathrm{~L} 1)$, (b) $\mathrm{S}_{66} \mathrm{M}_{68}$ (L2), (c) $\mathrm{S}_{46} \mathrm{M}_{51}$ (L3), (d) $\mathrm{S}_{56} \mathrm{M}_{52}$ (L4), (e) $\mathrm{S}_{42} \mathrm{M}_{121}$ (C1), (f) $\mathrm{S}_{60} \mathrm{M}_{165}(\mathrm{C} 2)$, (g) $\mathrm{S}_{38} \mathrm{M}_{100}(\mathrm{C} 3)$ and (h) $\mathrm{S}_{100} \mathrm{M}_{39}(\mathrm{C} 4)$ from a heating cycle (room temperature up to $300{ }^{\circ} \mathrm{C}$ ) which was followed by a rapid quench to room temperature (final). The curves were shifted for clarity.

\subsection{Rheological properties of PS-b-PMMA diblock copolymers}

The rheological properties of the pristine diblock copolymers are discussed by analysis of the master curves at a reference temperature of $220{ }^{\circ} \mathrm{C}$ (see Figs. 4 and 5). The master curves were constructed by applying the time-temperature superposition principle and using the data at temperatures of $150{ }^{\circ} \mathrm{C}, 170{ }^{\circ} \mathrm{C}, 190{ }^{\circ} \mathrm{C}$ and $220^{\circ} \mathrm{C}$. Measurements at higher temperatures were not performed because of possible degradation of PMMA during the relatively long duration of shear oscillations. Since diblock copolymers consist of two different monomeric units which generally are associated with different Williams-Landel-Ferry shift factors, one cannot expect that the time-temperature superposition principle can be generally applied to diblock copolymers. Furthermore, morphological characteristics might change with temperature because of the temperature dependence of the Flory-Huggins interaction parameter $\chi$. Nevertheless, in this work master curves were constructed in order to demonstrate the quality of the fit and to discuss the frequency and time-dependent behaviour 
of the materials for the foaming process. For the samples SM(L2), SM(L4) and SM(C4), only three temperatures $\left(170^{\circ} \mathrm{C}, 190^{\circ} \mathrm{C}\right.$ and $\left.220^{\circ} \mathrm{C}\right)$ were used for the construction of master curves.
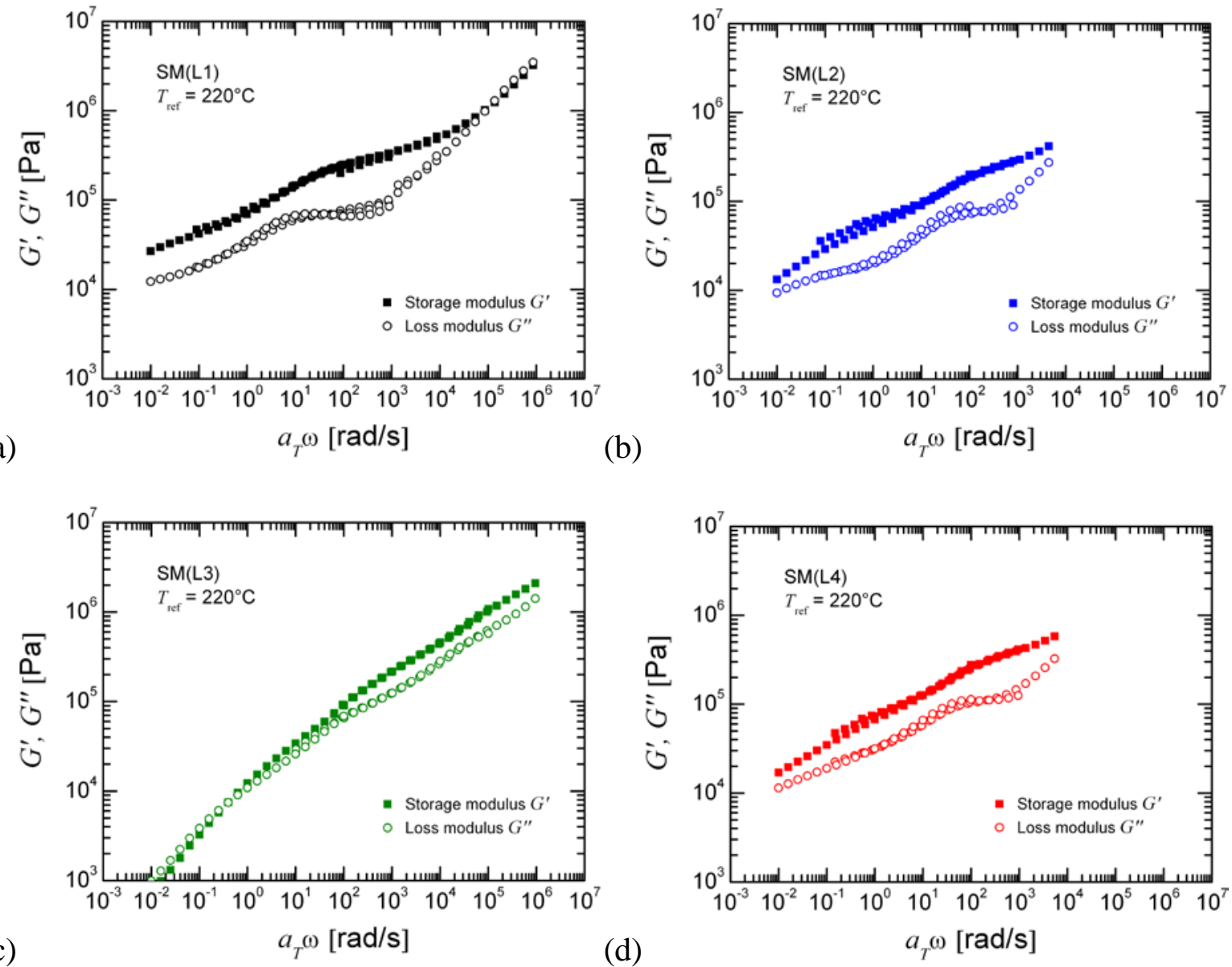

Figure 4. Master curves of $G^{\prime}$ and $G^{\prime \prime}$ as a function of angular frequency $\omega$ for the PS-b-PMMA diblock copolymers with a lamellar morphology: (a) $\mathrm{S}_{110} \mathrm{M}_{125}$ (L1), (b) $\mathrm{S}_{66} \mathrm{M}_{68}\left(\mathrm{~L} 2\right.$ ), (c) $\mathrm{S}_{46} \mathrm{M}_{51}$ (L3) and (d) $\mathrm{S}_{56} \mathrm{M}_{52}$ (L4). The reference temperature is $T_{\text {ref }}=220^{\circ} \mathrm{C}$. The shift factor is denoted by $a_{T}$.

The volume fraction of PMMA in the block copolymers with a lamellar morphology was 0.44 (see Table 1). The data for the high molecular weight diblock copolymers, i.e. $\mathrm{S}_{110} \mathrm{M}_{125}(\mathrm{~L} 1)$, $\mathrm{S}_{66} \mathrm{M}_{68}(\mathrm{~L} 2)$ and $\mathrm{S}_{56} \mathrm{M}_{52}(\mathrm{~L} 4)$, are presented in Figs. 4(a), (b) and (d). In the frequency range from $10 \mathrm{rad} / \mathrm{s}$ to $1000 \mathrm{rad} / \mathrm{s}$ the entanglement plateau appears with $G^{\prime}$ larger than $G^{\prime \prime}$. The width of this rubbery plateau attains the largest value for the block copolymer with the largest molecular weight, i.e. $\mathrm{S}_{110} \mathrm{M}_{125}(\mathrm{~L} 1)$, and the lowest value for the block copolymer with a lower molecular weight ( $\mathrm{S}_{56} \mathrm{M}_{52}(\mathrm{~L} 4)$ ). Furthermore, the cross over point of $G^{\prime}$ and $G^{\prime \prime}$ at low 
frequencies cannot be detected in the master curves since the block copolymers $\mathrm{S}_{110} \mathrm{M}_{125}(\mathrm{~L} 1)$, $\mathrm{S}_{66} \mathrm{M}_{68}(\mathrm{~L} 2)$ and $\mathrm{S}_{56} \mathrm{M}_{52}(\mathrm{~L} 4)$ are in the microphase-separated state up to our highest measurement temperature of $220{ }^{\circ} \mathrm{C}$. Consequently, the terminal regime of the Maxwell model with the power laws $G^{\prime} \sim \omega^{2}$ and $G^{\prime \prime} \sim \omega$ is not achieved in the accessible range of frequencies at our test parameters. The curves of $G^{\prime}$ and $G^{\prime \prime}$ in the low frequency range for the data of $\mathrm{S}_{110} \mathrm{M}_{125}(\mathrm{~L} 1)$ and $\mathrm{S}_{56} \mathrm{M}_{52}(\mathrm{~L} 4)$ are roughly parallel which corresponds to a power-law behaviour. Such a power-law with a power-law exponent in the order of $1 / 2$ is typical for block copolymers with a lamellar morphology, see, e.g., Ref. [54], and has been theoretically explained by Kawasaki and Onuki [39, 55].

The shape of the master curve of $\mathrm{S}_{46} \mathrm{M}_{51}(\mathrm{~L} 3)$ differs from the shape of the master curves of the three other block copolymers with a lamellar morphology. In the case of $\mathrm{S}_{46} \mathrm{M}_{51}(\mathrm{~L} 3)$, one can observe the beginning of the terminal regime (cross over of $G^{\prime}$ and $G^{\prime \prime}$ at low frequencies) with the power laws of the Maxwell model.

One possible explanation for the moderate quality of the time-temperature shift for the lamellar type block copolymers is the temperature dependence of $\chi N$. Russell et al. [36] determined the temperature dependent $\chi$ parameter of symmetric deuterated PS- $b$-PMMA block copolymers by SANS measurements. The temperature dependence of the $\chi$ parameter was given by $\chi=(0.028 \pm 0.002)+(3.9 \pm 0.06) / T$. In contrast to the present work, their studies were based on block copolymers with a low molecular weight $\left(M_{\mathrm{w}}=27000 \mathrm{~g} / \mathrm{mol}\right)$ with a total volume fraction of polystyrene equal to 0.44 . Recently, Cho and co-workers [40] studied the same system with SAXS and depolarized light scattering for a series of molecular weights. The net volume fraction of polystyrene in their system was nearly 0.54 . In the present study, the degree of polymerization of the systems chosen is in the order of 1000 and hence the factor $\chi N$ attains values between 32 and 78 at a temperature of $220{ }^{\circ} \mathrm{C}$. The different relaxation pattern observed for $\mathrm{S}_{46} \mathrm{M}_{51}(\mathrm{~L} 3)$ when compared to the other block copolymers is 
strongly influenced by the degree of polymerization in these systems which in turn affects the relaxation behaviour of PS and PMMA chains in block copolymers.
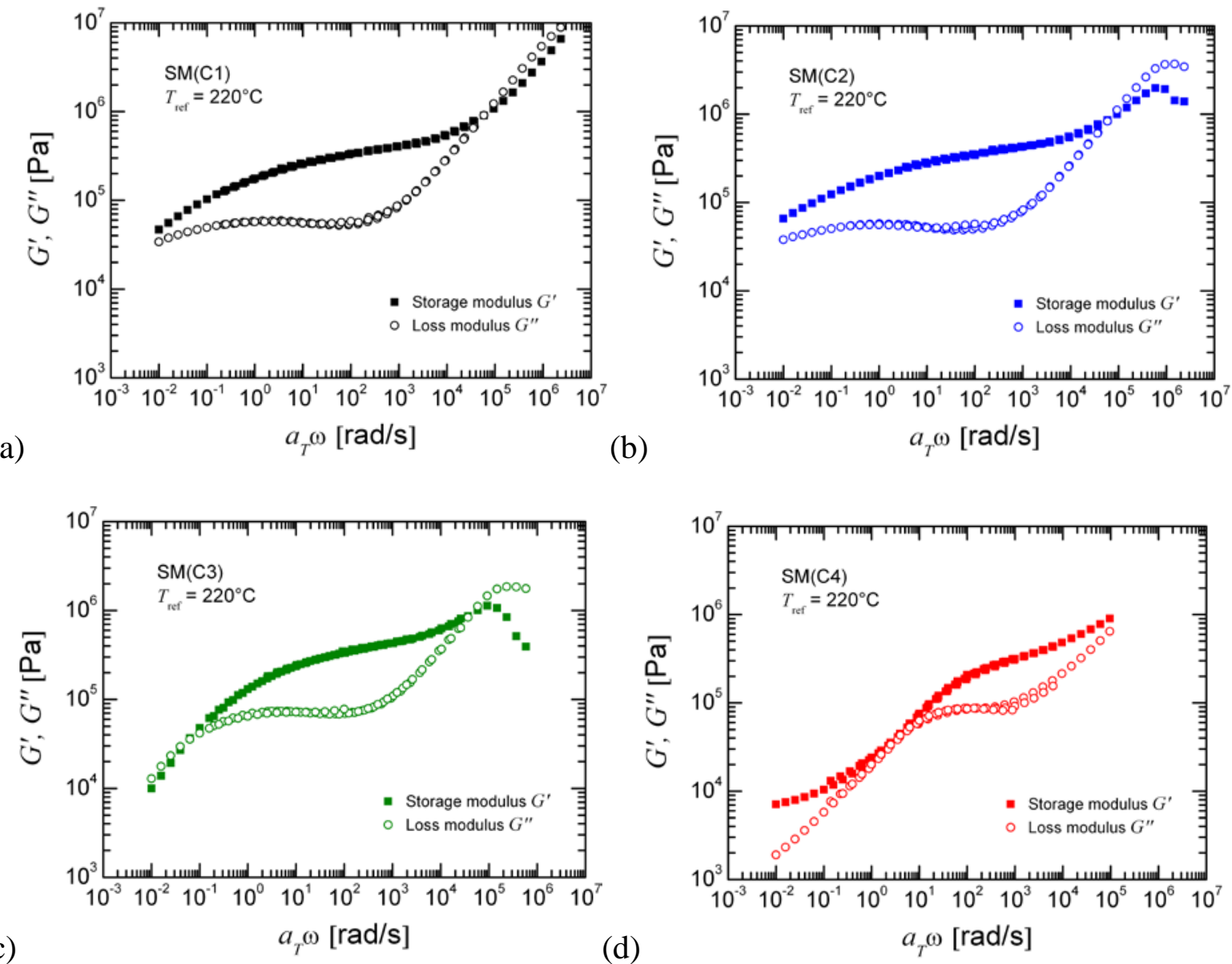

Figure 5. Master curves of $G^{\prime}$ and $G^{\prime \prime}$ as a function of angular frequency $\omega$ for the PS-b-PMMA diblock copolymers with a cylindrical morphology at $T_{\text {ref }}=220{ }^{\circ} \mathrm{C}$ : (a) $\mathrm{S}_{42} \mathrm{M}_{121}(\mathrm{C} 1)$, (b) $\mathrm{S}_{60} \mathrm{M}_{165}$ (C2), (c) $\mathrm{S}_{38} \mathrm{M}_{100}$ (C3) and (d) $\mathrm{S}_{100} \mathrm{M}_{39}(\mathrm{C} 4)$. The shift factor is denoted by $a_{T}$.

The master curves of the block copolymers with a cylindrical morphology and PMMA as the major component $\left(\mathrm{S}_{42} \mathrm{M}_{121}(\mathrm{C} 1), \mathrm{S}_{60} \mathrm{M}_{165}(\mathrm{C} 2)\right.$, and $\left.\mathrm{S}_{38} \mathrm{M}_{100}(\mathrm{C} 3)\right)$ are shown in Figs. 5(a)-(c). The composition of these block copolymers is asymmetric with a volume fraction of PMMA in the order of 0.72 . Similar to melts of homopolymers, the entanglement plateau with a larger value of storage modulus $\left(G^{\prime}\right)$ than loss modulus $\left(G^{\prime \prime}\right)$ can be clearly seen for all block copolymers with a cylindrical morphology. The comparison of the rubbery plateau in Figs. 5(c) and (d) reveals that the entanglement molecular weight $M_{\mathrm{e}}$ of PMMA is smaller than of PS. At higher frequencies, the transition of the polymers to the glassy regime is visible. At lower frequencies, the crossover of $G^{\prime}$ and $G^{\prime \prime}$ can only be seen for $\mathrm{S}_{38} \mathrm{M}_{100}(\mathrm{C} 3)$, since the 
molecular weight of the other two diblock copolymers $\mathrm{S}_{42} \mathrm{M}_{121}(\mathrm{C} 1)$ and $\mathrm{S}_{60} \mathrm{M}_{165}(\mathrm{C} 2)$ is larger than the one of $\mathrm{S}_{38} \mathrm{M}_{100}(\mathrm{C} 3)$. Because of the large molecular weight, these three diblock copolymers behave like entangled linear homopolymers in the accessible range of frequencies. Since the Flory-Huggins parameter $\chi$ for PS-PMMA diblock copolymers is larger than 0.028 [36] and the degree $N$ of polymerization larger than 1000 , we have $\chi N \geq 28$. For the diblock copolymers the volume fraction of the minor phase is at least 0.28 . Therefore we can assume that the diblock copolymers are microphase-separated at our test temperatures, see the phase diagram of Matsen and Bates [56].

The master curves of $\mathrm{S}_{100} \mathrm{M}_{39}(\mathrm{C} 4)$ differ from the ones of $\mathrm{S}_{42} \mathrm{M}_{121}(\mathrm{C} 1), \mathrm{S}_{60} \mathrm{M}_{165}(\mathrm{C} 2)$ and $\mathrm{S}_{38} \mathrm{M}_{100}(\mathrm{C} 3)$. At high frequencies the transition to the glassy regime is visible for $\mathrm{S}_{100} \mathrm{M}_{39}(\mathrm{C} 4)$. At low frequencies, the storage modulus $G^{\prime}$ depicts a plateau which is independent of $\omega$. This plateau is caused by the cylindrical morphology. Such an $\omega$ independent plateau indicates a solid-like behaviour at large times.

The silica content in the composites was $1 \mathrm{wt} \%$. In Fig. 6, the dynamic moduli of two diblock copolymers with a cylindrical and lamellar morphology, respectively, and their composites are presented at a temperature of $220{ }^{\circ} \mathrm{C}$. The addition of PMMA modified silica nanoparticles only has a minor influence on the dynamic moduli $G^{\prime}$ and $G^{\prime \prime}$ for the lamellar type diblock copolymers. This effect is exemplified for the system $\mathrm{S}_{110} \mathrm{M}_{125}(\mathrm{~L} 1)$ and its composite (see Fig. 6(a)). Similar to this composite with a lamellar morphology, the $G^{\prime}$ and $G^{\prime \prime}$ values of the diblock copolymer $\mathrm{S}_{42} \mathrm{M}_{121}(\mathrm{C} 1)$ with a cylindrical morphology are only slightly altered by the addition of silica nanoparticles (see Fig. 6(b)). In this case, the dynamic moduli are slightly higher than the dynamic moduli of the pristine diblock copolymer. 


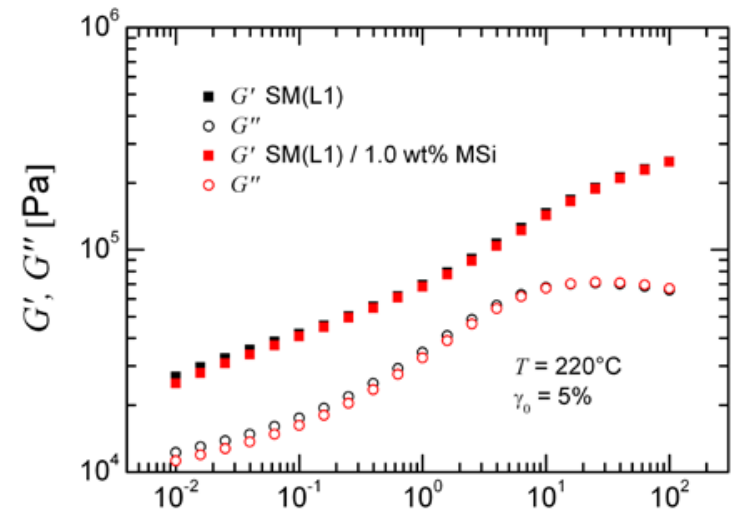

(a)

$\omega[\mathrm{rad} / \mathrm{s}]$

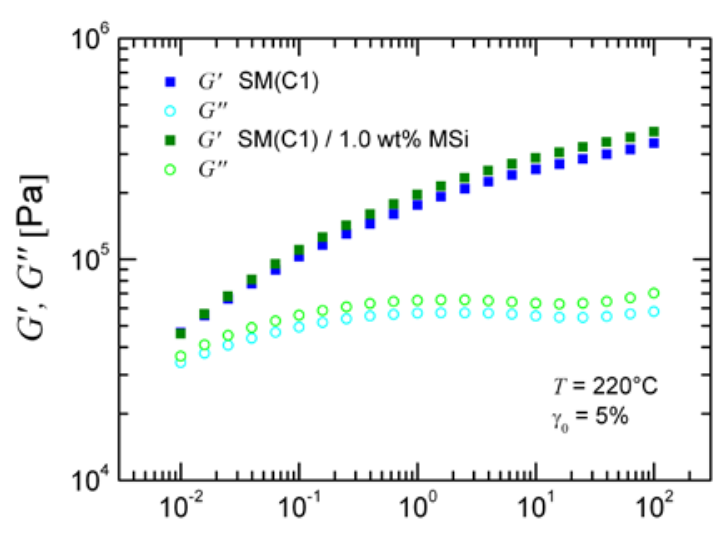

(b)

$\omega[\mathrm{rad} / \mathrm{s}]$

Figure 6. Variation of storage modulus $G^{\prime}$ and loss modulus $G^{\prime \prime}$ with angular frequency $\omega$ for diblock copolymers and their composites with a lamellar and a cylindrical morphology. In (a) the matrix was $\mathrm{S}_{110} \mathrm{M}_{125}(\mathrm{~L} 1)$ and in (b) $\mathrm{S}_{42} \mathrm{M}_{121}(\mathrm{C} 1)$, respectively. The test temperature was $220^{\circ} \mathrm{C}$.
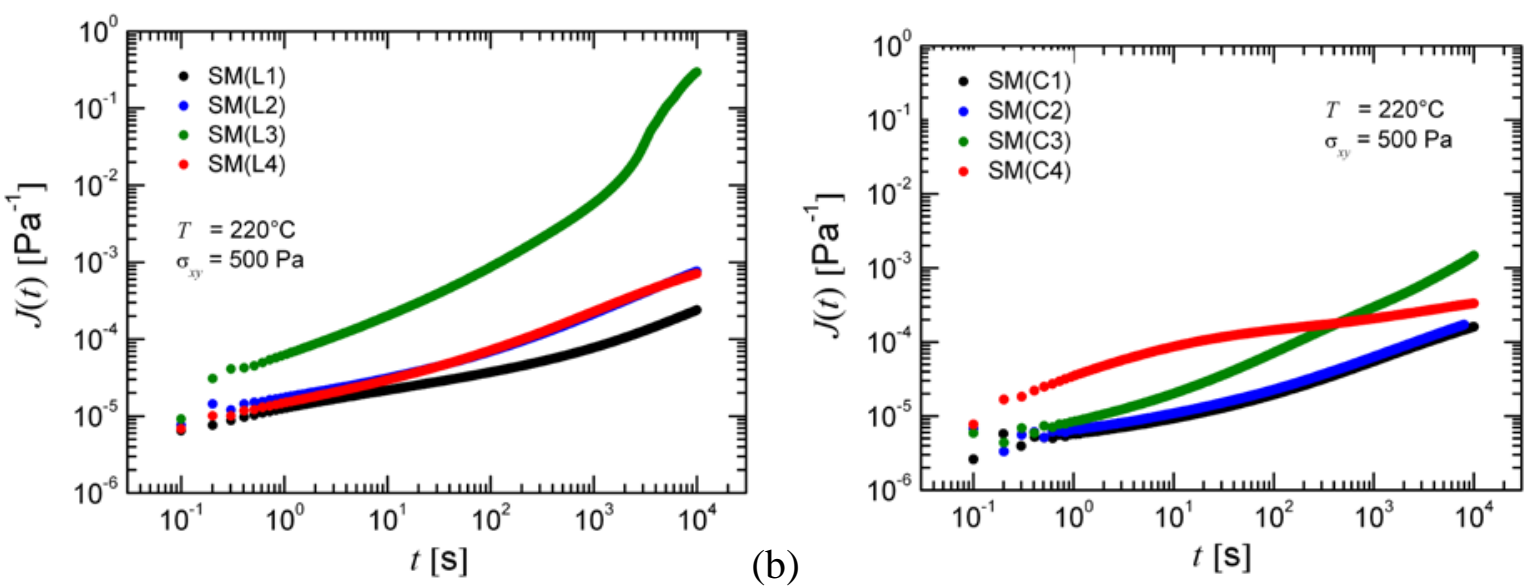

Figure 7. Creep compliance $J(t)$ of the block copolymers as a function of time $t$ for (a) the SM(L) series and (b) the $\mathrm{SM}(\mathrm{C})$ series at $220^{\circ} \mathrm{C}$. The creep stress and the creep time were $500 \mathrm{~Pa}$ and $10000 \mathrm{~s}$, respectively.

Shear oscillations in the linear viscoelastic range only allow one to determine the rheological properties at frequencies and time scales, respectively, in a range which is limited to four decades. In order to probe the viscoelastic properties at large times, creep experiments were performed, see also Ref. [57]. Note that the rheological behaviour at large times generally corresponds to the rheological response at higher temperatures according to the timetemperature superposition principle.

The time-dependent creep compliance $J(t)=\gamma(t) / \sigma_{0}$ of the pristine block copolymers is shown in Fig. 7 where $\gamma$ denotes the measured shear strain and $\sigma_{0}$ the applied shear stress. The creep 
compliance of the lamellar block copolymers $\mathrm{S}_{110} \mathrm{M}_{125}(\mathrm{~L} 1), \mathrm{S}_{66} \mathrm{M}_{68}(\mathrm{~L} 2)$ and $\mathrm{S}_{56} \mathrm{M}_{52}(\mathrm{~L} 4)$ corresponds to the results of the linear viscoelastic shear oscillations (cf. Fig. 1). Because of the large molecular weight, the creep compliance $J(t)$ of $\mathrm{S}_{110} \mathrm{M}_{125}(\mathrm{~L} 1)$ attains the lowest values, whereas the creep compliances of $\mathrm{S}_{66} \mathrm{M}_{68}(\mathrm{~L} 2)$ and $\mathrm{S}_{56} \mathrm{M}_{52}(\mathrm{~L} 4)$ do not differ much.

The creep curves of the comparatively low molecular weight block copolymer $\mathrm{S}_{46} \mathrm{M}_{51}$ (L3) (see Fig. 7(a)) attains a much larger creep compliance $J(t)$ than the other three systems with a lamellar morphology, since the molecular weight of the PS block is lowest in the $\mathrm{S}_{46} \mathrm{M}_{51}(\mathrm{~L} 3)$ block copolymer. This result is in qualitative accordance with the corresponding behaviour of the dynamic moduli with angular frequency, see Fig. 3(c).

The dependence of the creep compliance $J(t)$ on time (see Fig. 7(b)) of the cylindrical block copolymers $\mathrm{S}_{42} \mathrm{M}_{121}(\mathrm{C} 1)$ and $\mathrm{S}_{60} \mathrm{M}_{165}(\mathrm{C} 2)$ also qualitatively agrees with the data obtained from their master curves in Figs. 4(a) and (b). Since the dynamic moduli of $\mathrm{S}_{42} \mathrm{M}_{121}(\mathrm{C} 1)$ and $\mathrm{S}_{60} \mathrm{M}_{165}(\mathrm{C} 2)$ do not differ much, the creep compliances $J(t)$ of these two block copolymers are almost equal. The molecular weight of the block copolymer $\mathrm{S}_{38} \mathrm{M}_{100}(\mathrm{C} 3)$ is much lower than the molecular weight of $\mathrm{S}_{42} \mathrm{M}_{121}(\mathrm{C} 1)$ and $\mathrm{S}_{60} \mathrm{M}_{165}(\mathrm{C} 2)$. Consequently, the creep compliance of $\mathrm{S}_{38} \mathrm{M}_{100}(\mathrm{C} 3)$ is much larger than the creep compliance of $\mathrm{S}_{42} \mathrm{M}_{121}(\mathrm{C} 1)$ and $\mathrm{S}_{60} \mathrm{M}_{165}(\mathrm{C} 2)$. Similar to the results of the shear oscillations in the linear viscoelastic range, the timedependence of the creep compliance of $\mathrm{S}_{100} \mathrm{M}_{39}(\mathrm{C} 4)$ differs from the $J(t)$ values of the other three block copolymers with a cylindrical morphology. The creep compliance $J(t)$ of $\mathrm{S}_{100} \mathrm{M}_{39}(\mathrm{C} 4)$ attains an almost constant value at creep times larger than $1000 \mathrm{~s}$. This behaviour corresponds to the $\omega$-independent plateau of $G^{\prime}$ at low frequencies, see Fig. 5(d). 


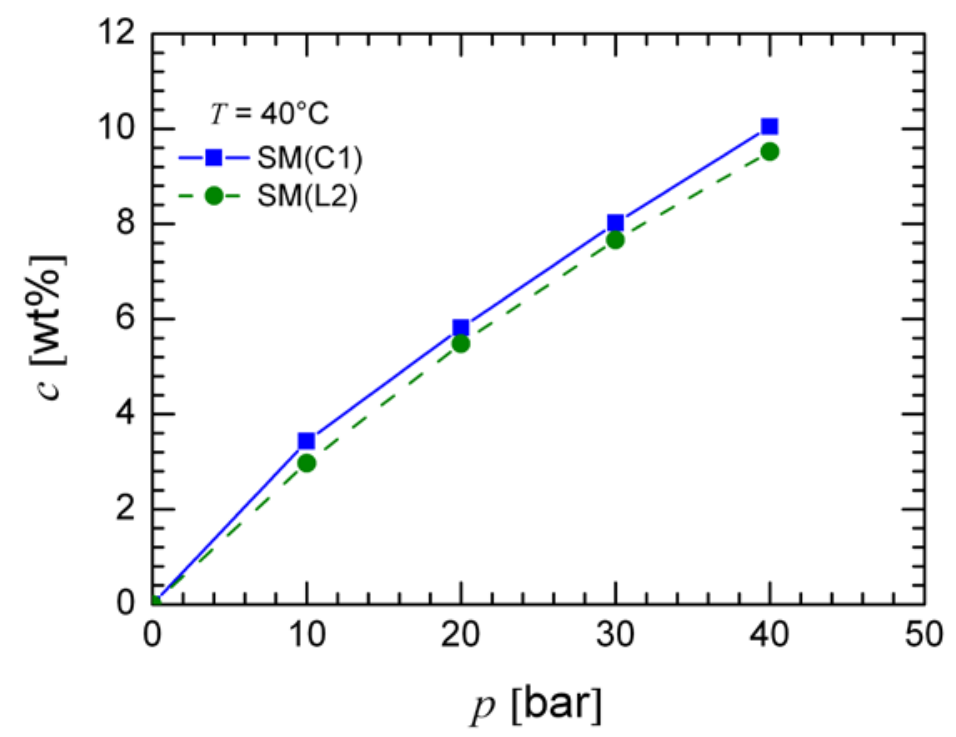

Figure 8. Results of sorption measurements. The data show the concentration (specific uptake) of carbon dioxide which is dissolved in two block copolymers (SM(C1) and SM(L2)) as a function of pressure $p$.

\subsection{Influence of carbon dioxide on the glass transition temperatures}

The results of sorption measurements for two different block copolymers are presented in Fig. 8. The amount of carbon dioxide which is dissolved in the block copolymers linearly increases with pressure $p$. The Henry's constant $k_{H}=p / c$ is given by $k_{H}=(3.4 \pm 0.4) \times 10^{7} \mathrm{~Pa}$ for $\mathrm{SM}(\mathrm{C} 1)$ and $k_{H}=(3.6 \pm 0.2) \times 10^{7} \mathrm{~Pa}$ for $\mathrm{SM}(\mathrm{L} 2)$. In units of $\mathrm{kg} \mathrm{MPa} / \mathrm{cm}^{3}(\mathrm{STP})$ with the density of carbon dioxide equal to $1.977 \mathrm{~kg} / \mathrm{m}^{3}$ at standard temperature and pressure one has $k_{H}=6.8 \times 10^{-5} \mathrm{~kg} \mathrm{MPa} / \mathrm{cm}^{3}(\mathrm{STP})$ for $\mathrm{SM}(\mathrm{C} 1) k_{H}=7.2 \times 10^{-5} \mathrm{~kg} \mathrm{MPa} / \mathrm{cm}^{3}(\mathrm{STP})$ for SM(L2). Generally, the solubility of $\mathrm{CO}_{2}$ in $\mathrm{SM}(\mathrm{L} 2)$ is slightly smaller than in SM(C1).

The thermal properties of the diblock copolymers are associated with two glass transition temperatures which result from the PS and the PMMA domains, respectively. The variation of the glass transition temperature $T_{\mathrm{g}}$ of PS and PMMA blocks in SM(L) and SM(C) diblock copolymers in a carbon dioxide atmosphere at different pressures (1 bar, 10 bar, 20 bar) is shown in Figs. 9 and 10. Measurements at higher pressures were not possible because the fluctuations of the baseline were too large. The $T_{\mathrm{g}}$ values for the PS and PMMA domains in all diblock copolymers decrease with pressure which indicates the dissolution of $\mathrm{CO}_{2}$ in both PS and PMMA domains. This results agrees with the sorption data in Fig. 8, since an 
increasing pressure leads to a more pronounced depression of $T_{g}$. In general, irrespective of nearly symmetric (lamellar type) or asymmetric (cylindrical type) composition of PS and PMMA, a similar behaviour towards $T_{\mathrm{g}}$ values with $\mathrm{CO}_{2}$ pressure was observed for all diblock copolymers of this study.
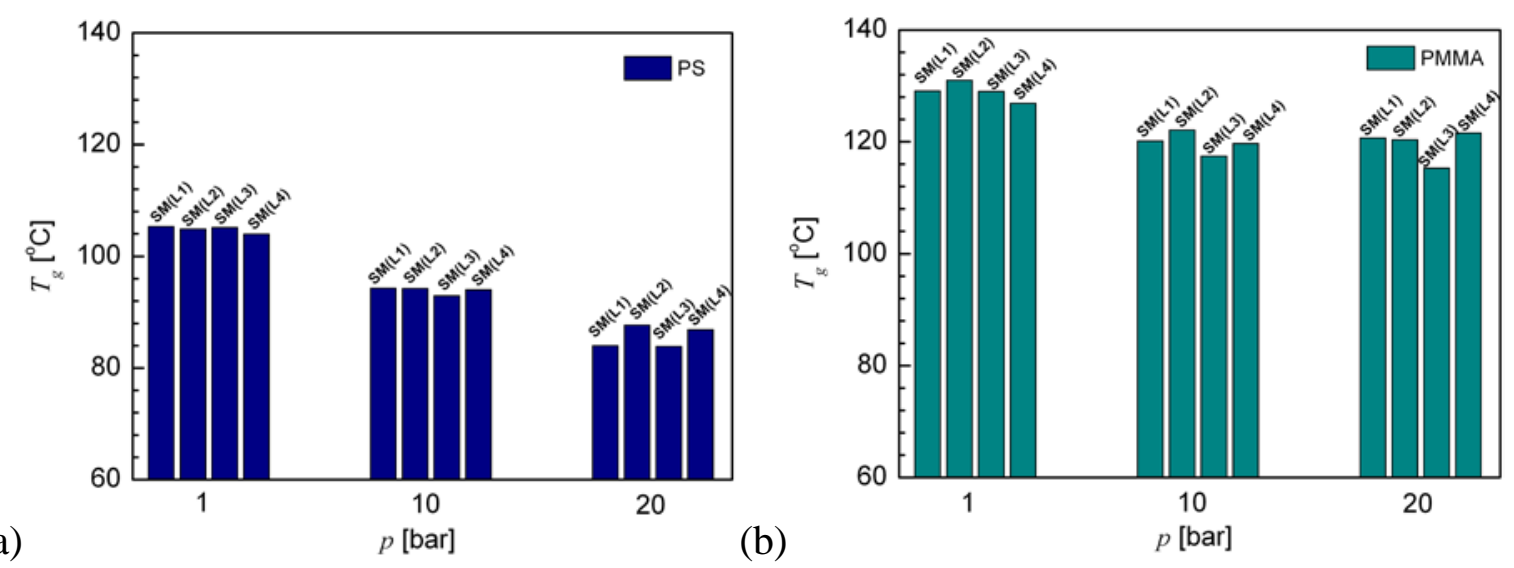

Figure 9. Glass transition temperature $T_{\mathrm{g}}$ as a function of pressure $p$ in (a) PS and (b) PMMA domains of the diblock copolymers with a lamellar morphology (SM(L)).
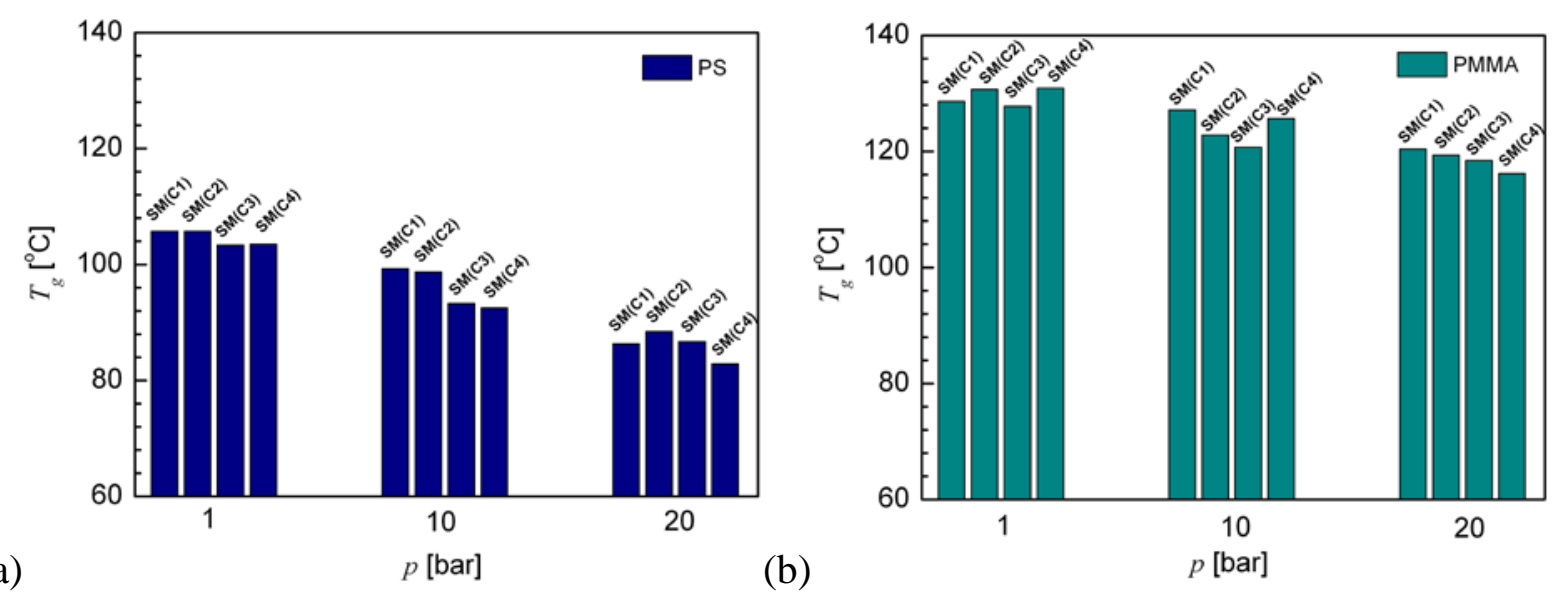

Figure 10. Glass transition temperature $T_{\mathrm{g}}$ as a function of pressure $p$ in (a) PS and (b) PMMA domains of the diblock copolymers with a cylindrical morphology $(\mathrm{SM}(\mathrm{C}))$.

\subsection{Scanning electron microscopic investigations of the foam morphology}

All diblock copolymer specimens were pressurized with carbon dioxide at a temperature of 40 ${ }^{\circ} \mathrm{C}$ and a pressure of 40 bar. The saturation concentration of carbon dioxide was approximately $10 \mathrm{wt} \%$ at these conditions (Fig. 8). The foaming experiments were carried out at $220^{\circ} \mathrm{C}, 260{ }^{\circ} \mathrm{C}$ and $300{ }^{\circ} \mathrm{C}$ using films cast from the solvent tetrahydrofuran, respectively.

The results of the scanning electron microscopic investigations are presented in Figs. 11 to 13.

The behaviour of the diblock copolymers with a lamellar morphology towards foam 
formation is exemplified by Fig. 11 for $\mathrm{S}_{56} \mathrm{M}_{52}(\mathrm{~L} 4)$ at a foaming temperature of $260{ }^{\circ} \mathrm{C}$. The morphology of foams of the diblock copolymers with a lamellar morphology indicates that they are less feasible towards foam formation than the diblock copolymers with a cylindrical morphology. The expansion ratio of the foams with a lamellar morphology is not very large and the foam cells are very irregular with a non-spherical shape such that mainly distorted cells have been formed. Even an increase of the foaming temperature up to $300{ }^{\circ} \mathrm{C}$ does not lead to a significant increase of the cell size. This effect can be attributed to the inherent behaviour of the lamellar morphology of diblock copolymers towards foaming. A possible reason for this moderate expansion ratio is the stability of lamellar domains, i.e. the energy needed for the cell growth is high. These results indicate that the stress which is necessary to deform the lamellae during cell nucleation and growth is too large, see also the melt elongation experiments in Ref. [58]. Irrespective of the chosen molecular weights and composition, diblock copolymers with a lamellar morphology show a similar behaviour during foaming. The addition of $\mathrm{M}_{21} \mathrm{Si}$ particles to the lamellar systems does not show a significant nucleating effect while foaming at our foaming temperatures. This effect is possibly caused by an incomplete dispersion of nanoparticles (presence of agglomerates) in the block copolymer, see Fig. 1(b). The density of the foams of the diblock copolymers with a lamellar morphology varies between $0.74-0.86 \mathrm{~g} / \mathrm{cm}^{3}$.

(a)
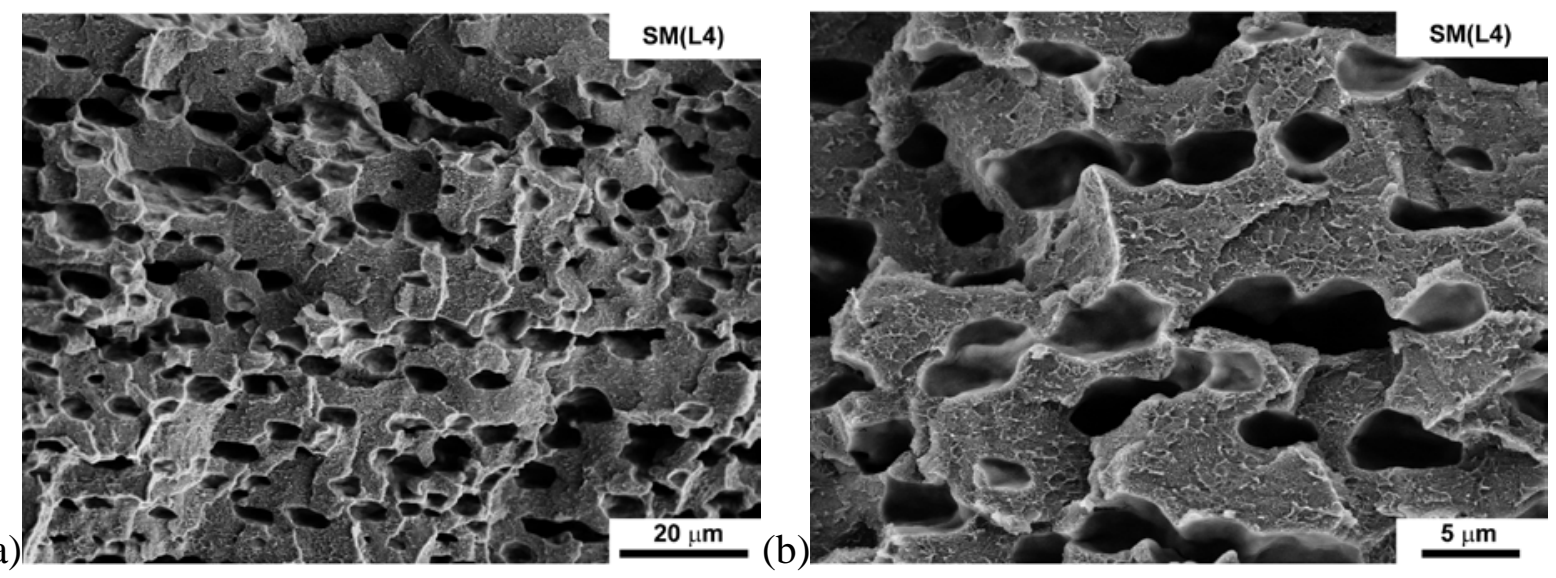

Figure 11. Scanning electron micrographs of cross section of a lamellar type diblock copolymer after foaming at $260{ }^{\circ} \mathrm{C}$. The polymer was $\mathrm{S}_{56} \mathrm{M}_{52}$ (L4). 

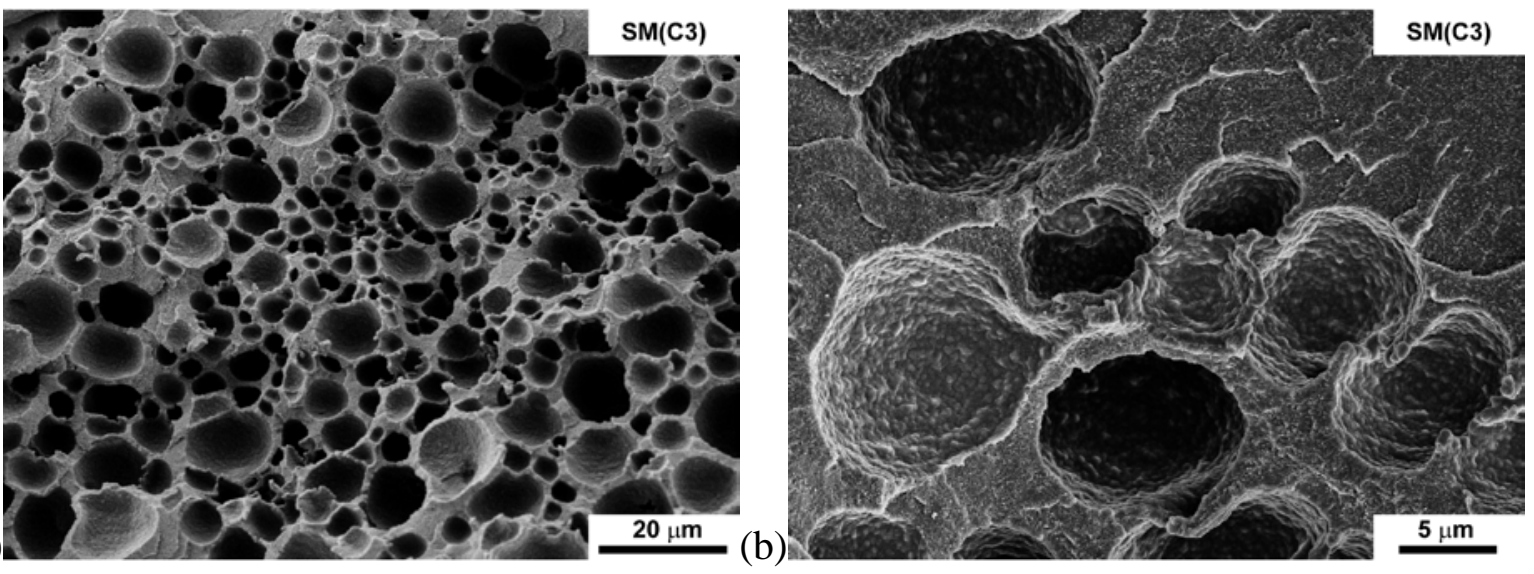

Figure 12. Scanning electron micrographs of cross sections of cylindrical type diblock copolymers and their composites after foaming experiment at $260^{\circ} \mathrm{C}$. The material was $\mathrm{S}_{38} \mathrm{M}_{100}(\mathrm{C} 3)$.

In spite of their large molecular weight, the block copolymers with a cylindrical morphology are more facile towards foaming experiments. This can be viewed by the expansion ratio of cells in the diblock copolymer and the density of the foam.

Figure 12 presents the scanning electron micrographs of the diblock copolymer $\mathrm{S}_{38} \mathrm{M}_{100}(\mathrm{C} 3)$ after foaming at $260{ }^{\circ} \mathrm{C}$. In comparison to the diblock copolymers with a lamellar morphology, the cells of the $\mathrm{S}_{38} \mathrm{M}_{100}(\mathrm{C} 3)$ foam attain a more spherical shape. The diameter of the cells is in the micrometre range. The variation of the foaming temperature did not lead to significant changes of the foam structure. The main conclusion of these experiments is that the molecular weight of these diblock copolymers with a PMMA matrix is too large such that the viscosity is too high in order to achieve a large expansion ratio in spite of the plasticizing effect of carbon dioxide.

In contrast to $\mathrm{S}_{38} \mathrm{M}_{100}(\mathrm{C} 3)$, polystyrene forms the major phase in the diblock copolymer $\mathrm{S}_{100} \mathrm{M}_{39}(\mathrm{C} 4)$. The scanning electron micrographs of pristine $\mathrm{S}_{100} \mathrm{M}_{39}(\mathrm{C} 4)$ shows a cellular structure after foaming at $260{ }^{\circ} \mathrm{C}$, see Fig. 13(a). As discussed in Section 3.2, the rheological behaviour of $\mathrm{S}_{38} \mathrm{M}_{100}(\mathrm{C} 3)$ and $\mathrm{S}_{100} \mathrm{M}_{39}(\mathrm{C} 4)$ differs in the low frequency range resp. at large creep times. Foaming of $\mathrm{S}_{100} \mathrm{M}_{39}(\mathrm{C} 4) / 1$ wt $\% \mathrm{M}_{21} \mathrm{Si}$ at $260{ }^{\circ} \mathrm{C}$ yields a "bee hive” like structure in the presence of $\mathrm{M}_{21} \mathrm{Si}$ particles (see Figs. 13(b) and (c)). The density of the resultant cell structure considerably reduced to $0.26-0.30 \mathrm{~g} / \mathrm{cm}^{3}$. The foam structure of the 
pristine diblock copolymer $\mathrm{S}_{100} \mathrm{M}_{39}(\mathrm{C} 4)$ at $260{ }^{\circ} \mathrm{C}$ and $300{ }^{\circ} \mathrm{C}$ shows the cylindrical morphology on the surface of the cell walls as well as on the surface of the sample (see Fig. 13(d) and (e)). This result indicates that it is possible to prepare multiscale structured polymer foams based on diblock copolymers. The multiscale structure arises from the microphase separation of the PS and the PMMA domains in the range of 30 nanometres and the structure of the foam cells in the micrometre range. Consequently, foaming of microphase separating diblock copolymers opens the route for preparation of tailored materials for a variety of applications. The above results and interpretations were based on foaming experiments carried out with diblock copolymer specimens pressurized with $\mathrm{CO}_{2}$ at 40 bar and $40{ }^{\circ} \mathrm{C}$. One can anticipate varying cell structures (open or closed) in foams by changing the experimental conditions.

(a)
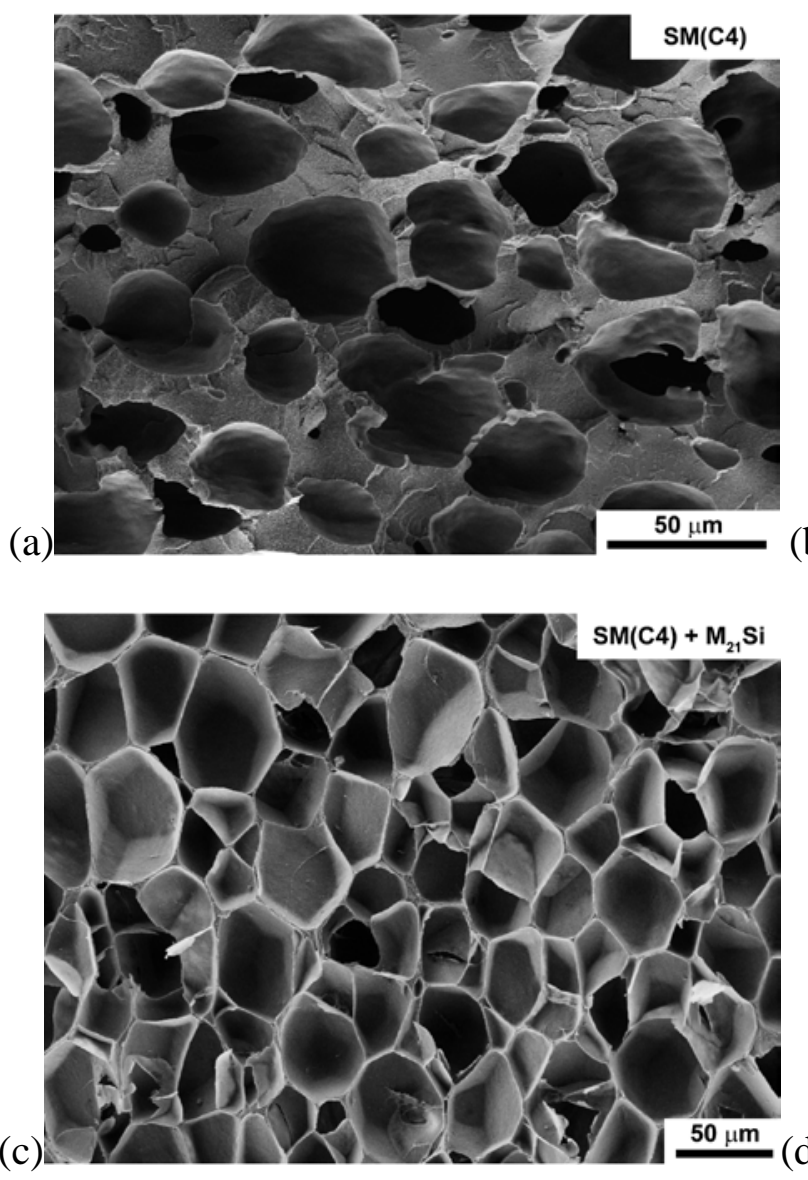

(b)
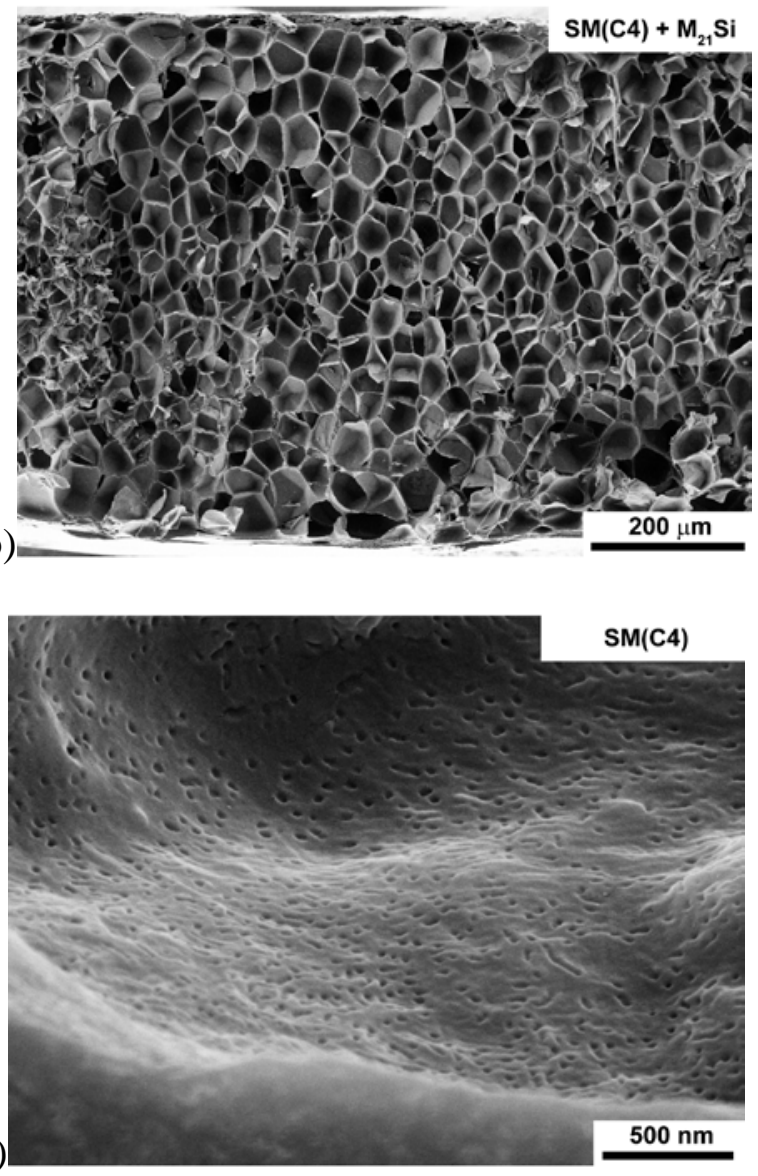
(e)

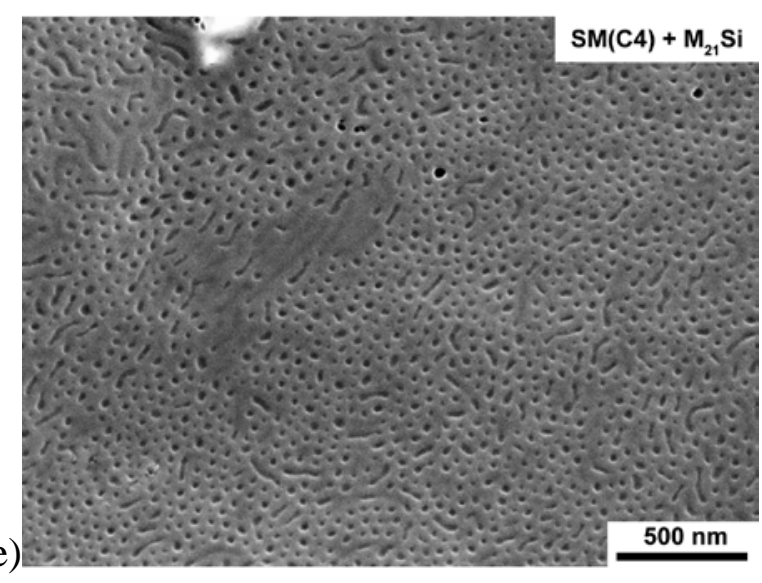

Figure 13. Scanning electron micrographs of cross sections of the diblock copolymer $S_{100} M_{39}(C 4)$ with a cylindrical morphology and a polystyrene matrix after batch foaming. (a) Pristine $\mathrm{S}_{100} \mathrm{M}_{39}(\mathrm{C} 4)$ diblock copolymer after foaming at $260{ }^{\circ} \mathrm{C}$. (b) $\mathrm{S}_{100} \mathrm{M}_{39}(\mathrm{C} 4) / 1$ wt $\% \mathrm{M}_{21} \mathrm{Si}$ composite after foaming at $260{ }^{\circ} \mathrm{C}$. (c) $\mathrm{S}_{100} \mathrm{M}_{39}(\mathrm{C} 4) / 1 \mathrm{wt} \% \mathrm{M}_{21} \mathrm{Si}$ composite after foaming at $260{ }^{\circ} \mathrm{C}$. (d) $\mathrm{S}_{100} \mathrm{M}_{39}(\mathrm{C} 4)$ after foaming at $300{ }^{\circ} \mathrm{C}$. (e) $\mathrm{S}_{100} \mathrm{M}_{39}(\mathrm{C} 4) / 1 \mathrm{wt} \% \mathrm{M}_{21} \mathrm{Si}$ composite after foaming at $300^{\circ} \mathrm{C}$. In micrograph (e), the PMMA domains appear in dark and the PS matrix in light grey.

\subsection{Density measurement and pore size distribution}

The density of the specimens after foaming at $220^{\circ} \mathrm{C}, 260{ }^{\circ} \mathrm{C}$ and $300{ }^{\circ} \mathrm{C}$ is presented in Fig. 14. The comparison of the data in Fig. 14(a) (diblock copolymers with a lamellar morphology) with the data in Fig. 14(b) (diblock copolymers with a cylindrical morphology) reveals that the diblock copolymers with a cylindrical morphology generally led to foams with a lower density. This result indicates a higher feasibility of diblock copolymers with a cylindrical morphology towards foam formation than the diblock copolymers with a lamellar microstructure. This result is surprising, since the dynamic moduli of the diblock copolymers with a cylindrical morphology at a frequency of $\omega=0.1 \mathrm{rad} / \mathrm{s}$ (corresponding to a time scale of $10 \mathrm{~s}$ ) are generally larger than the dynamic moduli of the diblock copolymers with a lamellar morphology. This result indicates that the behaviour of foam formation does not vary much with temperature for the diblock copolymers of this study. Irrespective of foaming temperature, the density of $\mathrm{S}_{110} \mathrm{M}_{125}(\mathrm{~L} 1)$ and $\mathrm{S}_{46} \mathrm{M}_{51}(\mathrm{~L} 3)$ block copolymers show density values in the range $0.78-0.85 \mathrm{~g} / \mathrm{cm}^{3}$. The addition of modified silica nanoparticles does not lead to a nucleation effect in our systems. A possible reason is the existence of agglomerates of nanoparticles in the composites. However, the foams prepared from $\mathrm{S}_{66} \mathrm{M}_{68}(\mathrm{~L} 2) / 1 \mathrm{wt} \%$ 
$\mathrm{M}_{21} \mathrm{Si}$ and $\mathrm{S}_{56} \mathrm{M}_{52}(\mathrm{~L} 4) / 1 \mathrm{wt} \% \mathrm{M}_{21} \mathrm{Si}$ have a slight reduction in density (to a value of 0.75 $\mathrm{g} / \mathrm{cm}^{3}$ ) from their corresponding pristine counterparts.

The density of the foams prepared from pristine $\mathrm{S}_{42} \mathrm{M}_{121}(\mathrm{C} 1)$ have a density which varies from $0.85 \mathrm{~g} / \mathrm{cm}^{3}, 0.82 \mathrm{~g} / \mathrm{cm}^{3}$ to $0.74 \mathrm{~g} / \mathrm{cm}^{3}$ for the temperatures of $300{ }^{\circ} \mathrm{C}, 220^{\circ} \mathrm{C}$ and $260{ }^{\circ} \mathrm{C}$, respectively. The density of foams of the composite $\mathrm{S}_{42} \mathrm{M}_{121}(\mathrm{C} 1) / 1 \mathrm{wt} \% \mathrm{M}_{21} \mathrm{Si}$ decreases from $0.72 \mathrm{~g} / \mathrm{cm}^{3}$ at $220{ }^{\circ} \mathrm{C}$ to $0.58 \mathrm{~g} / \mathrm{cm}^{3}$ after foaming at $260{ }^{\circ} \mathrm{C}$. For $\mathrm{S}_{60} \mathrm{M}_{165}(\mathrm{C} 2)$ and $\mathrm{S}_{38} \mathrm{M}_{100}(\mathrm{C} 3)$, the density of the porous structures was $0.58 \mathrm{~g} / \mathrm{cm}^{3}$ and $0.62 \mathrm{~g} / \mathrm{cm}^{3}$ after foaming at $220^{\circ} \mathrm{C}$. By increasing the foaming temperature to $260{ }^{\circ} \mathrm{C}$, the density rises to $0.78 \mathrm{~g} / \mathrm{cm}^{3}$ and $0.68 \mathrm{~g} / \mathrm{cm}^{3}$, respectively. By further increasing the foaming temperature to $300{ }^{\circ} \mathrm{C}$, the above values reduces to $0.72 \mathrm{~g} / \mathrm{cm}^{3}$ and $0.65 \mathrm{~g} / \mathrm{cm}^{3}$ for $\mathrm{S}_{60} \mathrm{M}_{165}(\mathrm{C} 2)$ and $\mathrm{S}_{38} \mathrm{M}_{100}(\mathrm{C} 3)$, respectively. The number density of cells was calculated from scanning electron micrographs according to the method of Kumar and Suh [59]. The analysis of the cell size of several block copolymers of this study revealed that the cell density varied and was in the range of $10^{7}$ and $10^{9}$ cells $/ \mathrm{cm}^{3}$.

The diblock copolymer $\mathrm{S}_{100} \mathrm{M}_{39}(\mathrm{C} 4)$ specimen forms porous structures having nearly equal densities, $0.70 \mathrm{~g} / \mathrm{cm}^{3}, 0.67 \mathrm{~g} / \mathrm{cm}^{3}$ and $0.74 \mathrm{~g} / \mathrm{cm}^{3}$, at $220{ }^{\circ} \mathrm{C}, 260{ }^{\circ} \mathrm{C}$ and $300{ }^{\circ} \mathrm{C}$, respectively. After foaming of the composite $\mathrm{S}_{100} \mathrm{M}_{39}(\mathrm{C} 4) / 1 \mathrm{wt} \% \mathrm{M}_{21} \mathrm{Si}$, the density reduces from 0.58 $\mathrm{g} / \mathrm{cm}^{3}$ to $0.30 \mathrm{~g} / \mathrm{cm}^{3}$ at a temperature of $260{ }^{\circ} \mathrm{C}$ (see Fig. 13(b)). The sharp decrease in the density of porous structure is due to the occurrence of a "bee hive" like cellular structure (see Figs. 13(b) and (c)). These observations can be explained by a nucleating effect of $\mathrm{M}_{21} \mathrm{Si}$ particles in the above system for the given foaming temperature. The average density of cells in the foam structure of $\mathrm{S}_{100} \mathrm{M}_{39}(\mathrm{C} 4) / 1$ wt \% $\mathrm{M}_{21} \mathrm{Si}$ (see Figs. 13(b) and (c)) prepared at 260 ${ }^{\circ} \mathrm{C}$ was approximately $0.8 \times 10^{15}$ cells $/ \mathrm{cm}^{3}$. 


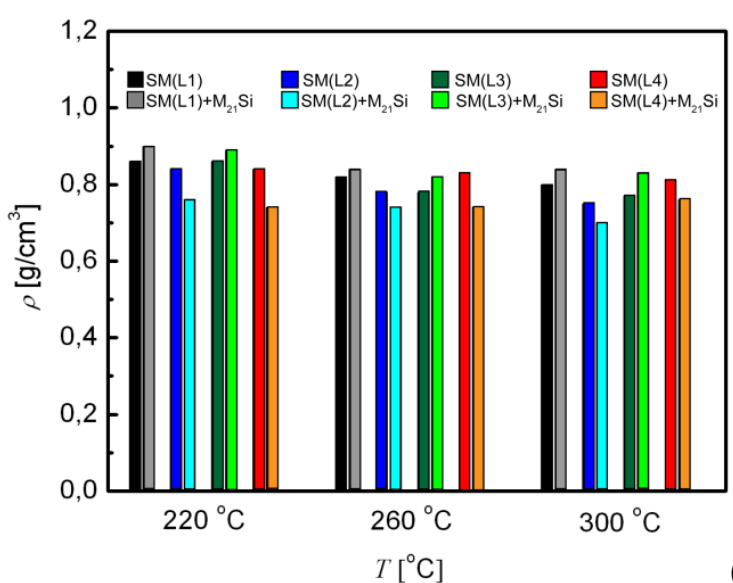

(a)

$T\left[^{\circ} \mathrm{C}\right]$

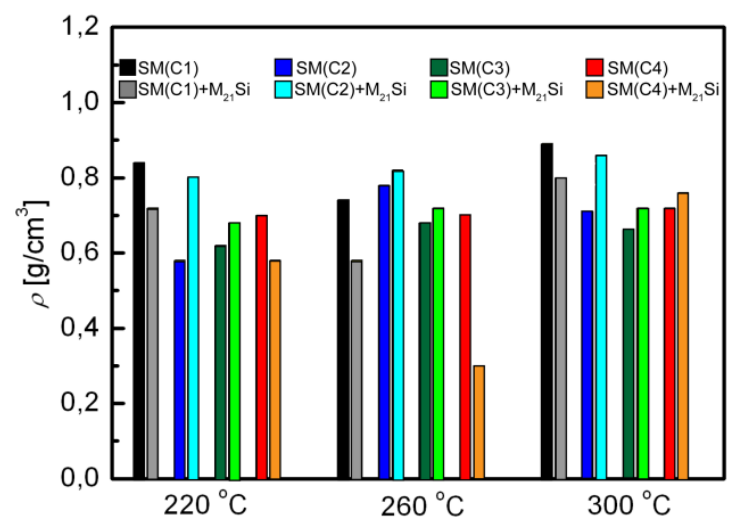

(b)

$T\left[{ }^{\circ} \mathrm{C}\right]$

Figure 14. Density $\rho$ of foams as a function of foaming temperature $T$ for the diblock copolymers and their composites with silica nanoparticles $\left(\mathrm{M}_{21} \mathrm{Si}\right)$ for specimens with (a) a lamellar morphology and (b) a cylindrical morphology.

\section{Conclusions}

In this study, the effect of morphology and molecular weight of PS- $b$-PMMA diblock copolymers on the formation of foams using $\mathrm{CO}_{2}$ as a blowing agent was investigated. Smallangle x-ray scattering experiments revealed that the diblock copolymers of this study were indeed in the microphase-separated state in the temperature range which corresponds to our foaming parameters. The microphase-separated morphology (lamellar or cylindrical microstructure) strongly influenced the dynamic moduli in the melt and led to a high viscosity and a large value of elasticity at processing temperature for the block copolymers of this study causing a moderate reduction of density. This work describes a first successful approach to prepare multiscale structured polymer materials with a foam cell structure in the micrometre range and a microphase separated structure with a typical length scale in the order of 30 nanometres. Such multiscale structured polymer foams may find applications in the field of polymer membranes and also as reactors in chemical engineering. Generally, the diblock copolymers with a cylindrical morphology led to foams with a lower density than the ones with a lamellar morphology. This effect can be explained by the large stresses which are necessary to deform the lamellar domains during cell nucleation and growth. The composite $\mathrm{S}_{100} \mathrm{M}_{39}(\mathrm{C} 4) / 1 \mathrm{wt} \% \mathrm{M}_{21} \mathrm{Si}$ with a polystyrene matrix yields cell structures with a density in the 
order of $0.3 \mathrm{~g} / \mathrm{cm}^{3}$. The morphology consists of a uniform cell structures after foaming at 260 ${ }^{\circ} \mathrm{C}$. The present work evokes the possibility of forming low dense cellular structures from PSb-PMMA block copolymers with a cylindrical morphology. The appearance of an $\omega$ independent plateau at low frequencies might be a necessary prerequisite for achieving such a structure. Our study reveals that the nature of the cell morphology of diblock copolymer foams does not only depend on foaming temperature and on the value of the dynamic moduli in the linear viscoelastic range, but also on the inherent microphase separated morphology.

\section{Acknowledgement}

The authors thank Dr. Volkan Filiz and Brigitte Lademann for the synthesis of diblock copolymers. They are grateful to Anne Schröder (scanning electron microscopy investigations), Dr. Jelena Lillepärg (sorption measurements), Ivonne Ternes (thermal analysis), Silvio Neumann (nuclear magnetic resonance studies) as well as Thorsten Wolff and Kristian Buhr for experimental support._Portions of this research were carried out at the light source DORIS III at DESY, a member of the Helmholtz Association (HGF). 


\section{References}

1. Hajduk DA, Gruner SM, Rangarajan P, Register RA, Fetters LJ, Honeker C, Albalak RJ, and Thomas EL. Macromolecules 1994;27:490-501.

2. Hamley IW, Castelletto V, Mykhaylyk OO, Yang Z, May RP, Lyakhova KS, Sevink GJA, and Zvelindovsky AV. Langmuir 2004;20:10785-10790.

3. Abetz V and Boschetti-de-Fierro A. Block Copolymers in the Condensed State. In: Matyjaszewski K and Möller M, editors., vol. 7, 2012. pp. 3-44.

4. $\quad$ Darling SB. Prog Polym Sci 2007;32:1152-1204.

5. $\quad$ Peinemann K-V, Abetz V, and Simon PFW. Nature Mater 2009;6:992-996.

6. $\quad$ Radjabian M, Koll J, Buhr K, Handge UA, and Abetz V. Polymer 2013;54:1803-1812.

7. Klempner D and Frisch KC. Handbook of Polymeric Foams and Foam Technology, 1991.

8. $\quad$ Lim GT, Altstädt V, Ramsteiner F, J Cell Plast 2009; 45: 419-439.

9. Ruckdäschel H, Gutmann P, Altstädt V, Schmalz H, and Müller AHE. Adv Polym Sci 2010;227:199-252.

10. Stumpf M, Spörrer A, Schmidt HW, and Altstädt V. J Cell Plast 2011;47:519-534.

11. Wolff F, Nicolat BC, Frey T, Greil P, and Münstedt H. Adv Eng Mater 2012;14:11101115 .

12. Tomasko DL, Li H, Liu D, Han X, Wingert MJ, Lee LJ, and Koelling KW. Ind Eng Chem Res 2003;42:6431-6456.

13. Ruiz JAR, Pedros M, Tallon J-M, and Dumon M. J Supercrit Fluids 2011;58:168-176.

14. Siripurapu S, DeSimone JM, Khan SA, and Spontak RJ. Macromolecules 2005;38:2271-2280.

15. Spitael P and Macosko CW. Polym Eng Sci 2004;44(11):2090-2100.

16. Ruckdäschel H, Rausch J, Sandler JKW, Altstädt V, Schmalz H, and Müller AHE. Polym Eng Sci 2008;48(11):2111-2125.

17. Lee M, Tzoganakis C, and Park CB. Polym Eng Sci 1998;38(7):1112-1120.

18. Mizoguchi K, Hirose T, Naito Y, and Kamiya Y. Polymer 1987;28:1298-1302.

19. Li Y, Wang X, Sanchez IC, Johnston KP, and Green PF. J. Phys. Chem. B 2007;111:16-25.

20. Wang W-C, Kramer EJ, and Sachse WH. J Polym Sci Polym Phys Ed 1982;20:13711384.

21. $\quad$ Park CB, Cheung LK, and Song SW. Cell Polym 1998;17(4):221-251.

22. Gutmann P, Hildebrandt K, and Altstädt V. J Cell Plast 2010;46(3):239-258.

23. Spitael P, Macosko CW, and McClurg RB. Macromol 2004;37(18):6874-6882.

24. Förster S, Khandpur AK, Zhao J, Bates FS, Hamley IW, Ryan AJ, and Bras W. Macromolecules 1994;27:6922-6935.

25. Fredrickson GH and Bates FS. Annu Rev Mater Sci 1996;26:501-550.

26. Leibler L. Macromolecules 1980;13:1602-1617.

27. Helfand E and Wasserman ZR. In: Developments in Block Copolymers, Goodman I (ed), Applied Science, New York, Chap. 4, 1982.

28. Matsen MW and Schick M. Phys Rev Lett 1994;72:2660-2663.

29. Watkins JJ, Brown GD, Rao VSR, Pollard MA, and Russell TP. Macromolecules 1999;32:7737-7740.

30. Lavery KA, Sievert JD, Watkins JJ, Russell TP, Ryu DY, and Kim JK. Macromolecules 2006;39:6580-6583.

31. Han CD and Kim J. J Polym Sci Polym Phys Ed 1987;25:1741-1764.

32. Han CD, Baek DM, Kim JK, Ogawa T, Sakamoto N, and Hashimoto T. Macromolecules 1995;28:5043-5062. 
33. Han CD, Vaidya NY, Kim D, Shin G, Yamaguchi D, and Hashimoto T. Macromolecules 2000;33:3767-3780.

34. Bates FS. Macromolecules 1984;17:2607-2613.

35. Bates FS, Rosedale JH, and Fredrickson GH. J Chem Phys 1990;92:6255-6270.

36. Russell TP, Hjelmjr RP, and Seeger PA. Macromolecules 1990;23:890-893.

37. Stühn B. J Polym Sci Part B: Polym Phys 1992;30:1013-1019.

38. Callaghan TA and Paul DR. Macromolecules 1993;26:2439-2450.

39. Zhao Y, Sivaniah E, and Hashimoto T. Macromolecules 2008;41:9948-9951.

40. Ahn H, Ryu DY, Kim Y, Kwon KW, Lee J, and Cho J. Macromolecules 2009;42:7897-7902.

41. Kim DH, Lau KHA, Joo W, Peng J, Jeong U, Hawker CJ, Kim JK, Russell TP, and Knoll W. J Phys Chem B 2006;110:15381-15388.

42. $\quad$ Li L, Yokoyama H, Nemoto T, and Sugiyama K. Adv Mater 2004;16:1226-1229.

43. Yokoyama H and Sugiyama K. Macromolecules 2005;38:10516-10522.

44. Li L, Nemoto T, Sugiyama K, and Yokoyama H. Macromolecules 2006;39:47464755.

45. Taki K, Waratani Y, and Ohshima M. Macromol Mater Eng 2008;293:589-597.

46. Zirkel L, Jakob M, and Münstedt H. J Supercritical Fluids 2009;49:103-110.

47. Physical Properties of Polymers (2nd ed.), Chapter 37, "Densities of Amorphous and Crystalline Polymers": Springer, New York, 2007.

48. Handge U and Altstädt V. J Rheol 2012;56(4):743-766.

49. $\quad$ Product Information Fluorinert ${ }^{\mathrm{TM}}$ Electronic Liquid FC-77 MC, St. Paul, MN 551441000, USA.

50. Operating Instructions XP/XS Analytical Balances: Mettler-Toledo AG, Greifensee, Switzerland, 2011.

51. Williams ML, Landel RF, and Ferry JD. J Am Chem Soc 1955;77:3701-3707.

52. Macosko CW. Rheology: Principles, Measurements and Applications, New York, VCH Publishers, 1994.

53. Chakkalakal GL, Alexandre M, Abetz C, Boschetti-de-Fierro A, and Abetz V. Macromol Chem Phys 2012;213(5):513-528.

54. $\quad$ Rosedale JH and Bates FS. Macromolecules 1990;23(8):2329-.

55. Kawasaki K and Onuki A. Phys Rev A 1990;42(6):3664-3666.

56. Matsen MW and Bates FS. Macromolecules 1996;29(4):1091-1098.

57. Triebel C, Kunzelmann P, Blankenburg M, and Münstedt H. Polymer 2011;52:36213626.

58. Handge UA, Buschnakowski M, and Michler GH. J Appl Polymer Sci 2009;112:13191329.

59. Kumar V and Suh NP. Polym Eng Sci 1990;30:1323-1329. 